\title{
Affordability of current diets and healthy, more equitable, sustainable diets, by area of socioeconomic disadvantage and remoteness in Queensland: Insights into the drivers of food choice
}

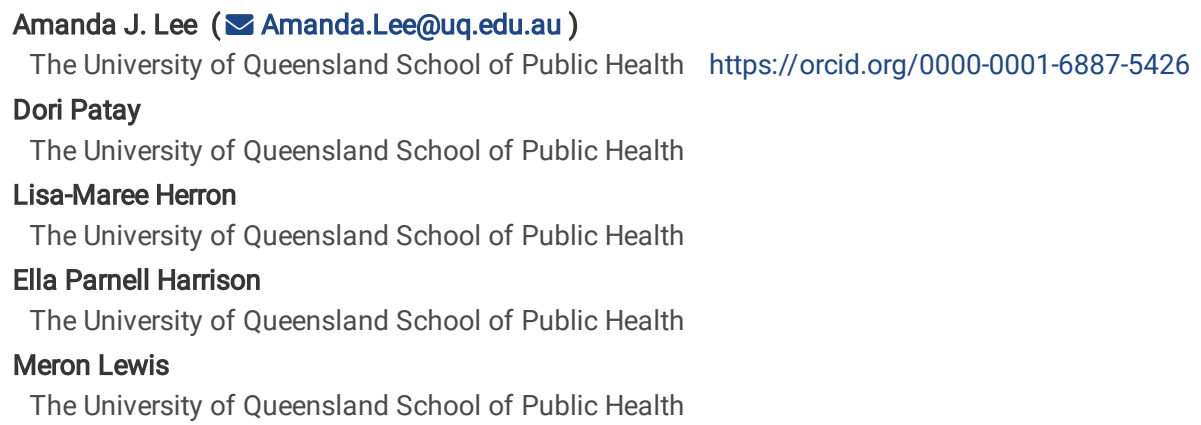




\section{Abstract \\ Background}

Poor diet is the leading preventable risk factor contributing to the burden of disease globally and in Australia, and is inequitably distributed. As the price of healthy foods is a perceived barrier to improved diets, evidence on the cost and affordability of current (unhealthy) and recommended (healthy, more equitable and sustainable) diets is required to support policy action.

\section{Methods}

This study applied the Healthy Diets ASAP (Australian Standardised Affordability and Pricing) methods protocol to measure the cost, cost differential and affordability of current and recommended diets for a reference household in Queensland, Australia. Food prices were collected in 18 randomly selected locations stratified by area of socioeconomic disadvantage and remoteness. Diet affordability was calculated for three income categories.

\section{Results}

Surprisingly, recommended diets would cost $20 \%$ less than the current diet in Queensland as a whole. Households spent around $60 \%$ of their food budget on discretionary choices (that is, those not required for health that are high in saturated fat, added sugar, salt and/or alcohol). Queensland families would need to spend around $23 \%$ of their income on recommended diets. However, recommended diets would not be affordable in low socioeconomic or very remote areas, costing $30 \%$ and $35 \%$ of median household income respectively. The government supplements due to the SARS-CoV-2 pandemic would improve affordability of recommended diets by $29 \%$.

\section{Conclusions}

Study findings highlight that, although price is one factor affecting consumer food choice, other drivers such as taste, convenience, advertising and availability are important too. Nevertheless, the study found that recommended diets would be unaffordable in very remote areas, and that low income families are likely experiencing food stress, irrespective of where they live in Queensland. Policy actions, such as increasing to $20 \%$ the current $10 \%$ Goods and Services tax differential between basic healthy, and unhealthy foods in Australia, and supplementing incomes of vulnerable households, especially in remote areas, are recommended to help improve diet equity and sustainability, and health and wellbeing for all.

\section{Background}

Poor diet is now the leading preventable risk factor contributing to the burden of disease, globally, and in Australia $(1,2)$. Poor diet is driven by food environments which encourage over-consumption of unhealthy options $(3,4)$. Hence there is growing need to understand drivers of food choices and support policy action that will improve food environments to shift population diets towards dietary recommendations.

Food price and affordability are significant contributors to food security and dietary $(5,6)$. Better information about the cost and affordability of habitual and recommended diets, is required to inform potential health and fiscal policy action, such as taxes and subsidies, to manipulate food pricing to promote healthier options (5, 7-9). To support comprehensive monitoring of food environments, the International Network on Food and Obesity/Noncommunicable disease (NCD) Research, Monitoring and Action Support (INFORMAS) has developed a step-wise framework to determine the cost and affordability of 'current' diets (based on reported intake in national surveys) and recommended healthy diets (consistent with dietary guidelines) (5).

This study assessed the cost, cost differential and affordability of current (unhealthy) and recommended (healthy, more equitable and sustainable) diets in the state of Queensland, Australia, by area of socioeconomic disadvantage and by remoteness. Given $67 \%$ of Australian adults and $25 \%$ of children aged two to 17 years are overweight or obese (10), and the high rates of poor-diet related outcomes in Australia (1), current diets are considered unhealthy. In Queensland, the prevalence of diet-related NCD is highest in remote locations and areas of socioeconomic disadvantage (11). The recommended diet is consistent with the Australian Dietary Guidelines 2013 (ADGs) (12). Contrary to recent claims (13), the recommended diet is more sustainable than the current Australian diet, being produced by food systems that use less water, support biodiversity and generate $25 \%$ less green-house emissions (14).

More evidence is needed also to better understand the relationships between household income and food choice (15-17). Hence, this study also assessed, opportunistically, the impact on diet affordability of income supplements introduced by the Australian Government during the SARS-CoV-2 pandemic in 2020 (18).

\section{Methods}

The aim of this study was to assess the cost, cost differential and affordability of current (unhealthy) and recommended (healthy, more equitable and sustainable) diets in the state of Queensland, Australia, by area of socioeconomic disadvantage and by remoteness. To achieve this, the Healthy Diets ASAP (Australian Standardised Affordability and Pricing) methods protocol (19) was applied. This protocol was developed to address the limitations of earlier approaches assessing food cost and affordability $(9,20)$. The protocol is consistent with the INFORMAS framework's 'optimal' approach to assess food price and affordability (5). The background, description, collaborative development process, application and testing of the protocol have been detailed elsewhere (8, 19). Therefore this paper offers contextualisation and a brief explanation of methods. The Healthy Diets ASAP protocol consists of five parts: standardised 
current (unhealthy) and recommended (healthy, more equitable and sustainable) diet pricing tools; store location and sampling; calculation of median gross and indicative low disposable income; food price data collection; and analysis and reporting (19).

\subsection{Diet pricing tools}

The current and recommended diet pricing tools contain the type and quantity of foods and drinks for the members of a reference household per fortnight based on intake reported in the most recent national nutrition survey data (21), and as recommended by ADGs (12), respectively. The quantities of food per fortnight were calculated for a reference household of four: an adult male 31-50 years old, an adult female 31-50 years old, a 14 year old boy and an 8 year old girl (19). The contents of the current and recommended diets are summarised in Table 1, detailed in Additional file 1, and illustrated pictorially elsewhere (22). The current diet includes some healthy food and drinks, but also 'discretionary' choices. Discretionary food and drinks are defined as those that are not a necessary part of a healthy diet and are high in saturated fat, added sugars, salt and/or alcohol (12). The recommended diet comprises the healthy food and drinks commonly consumed in the current diet in optimal quantities. The diets are similar in energy content: for the reference household the current diet provides $33,860 \mathrm{~kJ}$ per day and the recommended diet provides $33,610 \mathrm{~kJ}$ per day.

Table 1

Foods and drinks included in the Healthy Diets ASAP diet pricing tools (19)

\begin{tabular}{|c|c|}
\hline Current diet & Recommended (healthy, more equitable and sustainable) diet \\
\hline \multirow{2}{*}{$\begin{array}{l}\text { - Healthy foods and drinks as per the seven food groups on } \\
\text { the right; in reduced amounts reflecting reported intakes (ABS, } \\
\text { 2013) }\end{array}$} & - Water (bottled) \\
\hline & - Fruit: apples, bananas, oranges \\
\hline - Artificially sweetened beverages & \multirow{2}{*}{$\begin{array}{l}\text { - Vegetables: potatoes, broccoli, white cabbage, iceberg lettuce, onion, carrot, pumpkin, } \\
\text { tomatoes, sweetcorn (canned), four bean mix (canned), diced tomatoes (canned), baked } \\
\text { beans (canned), frozen mixed vegetables, frozen peas, salad vegetables in sandwich }\end{array}$} \\
\hline - Discretionary (unhealthy) foods and drinks: & \\
\hline o Drinks: sugar sweetened beverages & \multirow{2}{*}{$\begin{array}{l}\text { - Grain (cereals): wholegrain cereal biscuits }\left(\text { Weet-bix }^{\mathrm{TM}}\right) \text {, rolled oats, cornflakes, } \\
\text { wholemeal bread, white bread, white rice, white pasta, dry water crackers, bread in } \\
\text { sandwich }\end{array}$} \\
\hline $\begin{array}{l}\text { o Cereals, snacks and desserts: muffin, sweet biscuits, } \\
\text { savoury crackers, confectionary, chocolate, potato crisps, }\end{array}$ & \\
\hline $\begin{array}{l}\text { muesli bar, mixed nuts (salted), ice cream, fruit salad (canned } \\
\text { in juice) }\end{array}$ & $\begin{array}{l}\text { - Lean meats and alternatives: beef mince and steak, lamb chops, cooked chicken, tuna } \\
\text { (canned), eggs, peanuts (unsalted), meat in sandwich }\end{array}$ \\
\hline o Processed meats: beef sausages, ham & $\begin{array}{l}\text { - Milk, yoghurt and cheese: cheddar cheese (full fat, reduced fat), milk (full fat, reduced } \\
\text { fat), yoghurt (full fat plain, reduced fat flavoured) }\end{array}$ \\
\hline $\begin{array}{l}\text { o Spreads, sauces, condiments and ingredients: butter, } \\
\text { tomato sauce, salad dressing, white sugar }\end{array}$ & \multirow[t]{4}{*}{ - Unsaturated oils and spreads: olive oil, sunflower oil, canola (margarine) } \\
\hline $\begin{array}{l}\text { o Convenience meals: frozen lasagne, chicken soup (canned), } \\
\text { frozen fish fillet (crumbed), instant noodles, meat and } \\
\text { vegetable stew (canned) }\end{array}$ & \\
\hline o Fast food: pizza, meat pie, hamburger, potato chips/fries & \\
\hline $\begin{array}{l}\text { o Alcohol: beer (full strength), white wine (sparkling), red } \\
\text { wine, whisky }\end{array}$ & \\
\hline
\end{tabular}

\subsection{Store location and sampling}

In preparation for sampling, all Queensland locations at Statistical Area Level 2 (SA2) level were stratified by area of socioeconomic disadvantage and remoteness. SA2 areas are classified by the Australian Bureau of Statistics (ABS) as medium-sized geographical areas representing communities "that interact together socially and economically" (23). The four Socio-Economic Indexes for Areas (SEIFA) developed by the ABS rank SA2 locations based on a variety of census data (24).

The Index of Relative Socioeconomic Disadvantage (IRSD) was selected as the basis of socioeconomic disadvantage stratification in this study, and each SA2 area was assigned a quintile according to the relative IRSD ranking.

SEIFA quintile 1 comprises the most disadvantaged, and SEIFA quintile 5 the least disadvantaged SA2 locations.

Remoteness was defined by the Accessibility/Remoteness Index of Australia Plus (ARIA+) categorisation, which indicates the relative access to services in different locations (25). Levels of remoteness are expressed as: major cities, inner regional, outer regional, remote and very remote locations. Statistical Area 1 locations are geographically smaller than SA2 locations, so each SA2 location may include areas of varying designated ARIA + classification. To determine the most appropriate ARIA + classification, a concordance of the Queensland SA2s areas was developed, with Census data accessed to identify the population numbers at each level of remoteness within each SA2 (26). The level of remoteness with the largest population was then assigned to the SA2 for the purposes of this study.

Following assignment of socioeconomic disadvantage levels and remoteness levels, 18 SA2 locations (falling within SEIFA quintiles 1, 3 and 5 and ARIA + categories major cities, outer regional and very remote) were randomly selected in accordance with the Healthy Diets ASAP protocol (19).

As per the protocol, Google Maps was used to identify the prescribed food outlets within $7 \mathrm{~km}$ by car from the geographical centre of each SA2 location, including one outlet of each major supermarket chain and/or independent grocer, takeaway outlets of commonly consumed 'fast foods', independent bakeries and liquor stores (19).

\subsection{Calculation of household incomes}


In accordance with the Healthy Diets ASAP protocol (19), the median gross household income (before taxation, rent and other expenses) in each SA2 area was recorded, and an indicative low disposable household income for the reference household was calculated. The indicative low disposable household income was also calculated for a time point following the onset of the SARS-CoV-2 pandemic, in order to assess the impact of Additional income for people receiving income support payments (Economic Support Payment and Coronavirus Supplement) introduced by the Australian Government between May and September 2020 (18). Thus, this study assessed diet affordability for three categories of household income.

The median gross income for the reference household per fortnight at each SA2 location was sourced from the corresponding ABS 2016 Census Community Profile (27) and adjusted by ABS Wage Price Indices to June 2019 (28). The indicative calculated low disposable household income, based on a set of assumptions regarding the household, employment income at minimum wage, tax payable and eligible welfare payments provided by Services Australia (The Australian Government, 2020), was determined per fortnight for the reference household as detailed in the protocol (19), as at August 2019 and May 2020. Additional file 2 contains the detailed data and calculations for the indicative low disposable household income in 2019 and with the government supplements in 2020.

\subsection{Price data collection}

Seven volunteers from the Country Kitchens program (30), volunteer dietitians from Queensland Health and an Indigenous community-controlled health service, and three University of Queensland research assistants were trained in the strict application of the Healthy Diets ASAP data collection protocol, including use of the survey form (Additional file 3) to collect food and drink prices in designated stores in each included location across the state. For example, the data collection protocol outlines a procedure to follow if the stipulated brands and sizes were not available or were on price promotion (19). Permission to collect food prices from each store was requested and obtained immediately prior to data collection. Food prices were collected between May and October 2019.

\subsection{Analysis and reporting}

Two research assistants (EPH and ML) double entered, cross-checked and cleaned the data from the price data survey forms into Microsoft $\circledast$ Office Excel (2016) spreadsheets. As per the protocol, if a value was missing, the mean price of the item in other stores in the same SA2 location was substituted (19).

Diet costs and affordability were calculated for each SA2 location, then synthesised by area of socioeconomic disadvantage (SEIFA quintile) and remoteness (ARIA + category). The mean total costs of the current and recommended diets were calculated for the reference household per fortnight, as well as the cost and proportion of the total spent on different food groups and components of these (Tables 3A, 3B, and 3C). The affordability of current and recommended diets was calculated for households with the three household income amounts specified above. A diet was deemed to be unaffordable if it cost more than $30 \%$ of household income (7). If the diet cost more than $25 \%$ of disposable household income, the household was considered to be in food stress (17, 31 ).

\section{Results}

\subsection{Selected locations and stores}

The distribution of the randomly selected locations across SA2 areas of socioeconomic disadvantage (most, median, and least disadvantaged) and three ARIA + categories (major cities, outer regional, very remote) is presented in Table 2. None of the SA2 areas in Queensland was classified as both least disadvantaged and very remote, so no included location reflects this combination. One very remote area was a discrete Aboriginal community. Only one SA2 area was classified as median disadvantaged and very remote. In one of the 18 selected locations, data collection was not possible as management of the major food store in the community did not grant permission for food price data to be collected. Not all store types were available in each location, particularly in outer regional and very remote locations. Therefore, this paper describes the findings based on data collected in 17 locations and 125 food outlets.

Table 2

Stratification of the randomly selected SA2 locations based on area of socioeconomic disadvantage and remoteness

\begin{tabular}{|c|c|c|c|c|}
\hline & & \multicolumn{3}{|c|}{ Socioeconomic disadvantage (SEIFA) } \\
\hline & & $\begin{array}{l}\text { Most disadvantaged (SEIFA } \\
\text { quintile 1) }\end{array}$ & $\begin{array}{l}\text { Median disadvantaged (SEIFA } \\
\text { quintile } 3 \text { ) }\end{array}$ & $\begin{array}{l}\text { Least disadvantaged (SEIFA } \\
\text { quintile 5) }\end{array}$ \\
\hline \multirow{3}{*}{$\begin{array}{l}\text { Remoteness } \\
\text { (ARIA+) }\end{array}$} & Major cities & 3 & 4 & 3 \\
\hline & $\begin{array}{l}\text { Outer } \\
\text { regional }\end{array}$ & 2 & 2 & 1 \\
\hline & Very remote & $2^{*}$ & 1 & 0 \\
\hline
\end{tabular}

\subsection{Cost of current and recommended diets}

The total costs of the current and recommended diets in Queensland, by area of socioeconomic disadvantage, and by remoteness categories are presented respectively in Tables 3A, 3B, and 3C. These tables also display the cost of diet components by ADG food group, and of discretionary and healthy diet components, and the affordability of the different diets.

Overall, in Queensland, the mean cost of the current diet for the reference household was $A \$ 806.15 \pm 99.34$ per fortnight, which was $20 \%$ more expensive than the mean cost of the recommended diet at $\mathrm{A} \$ 644.25 \pm 66.28$ per fortnight (Table $3 \mathrm{~A}$ ). The current diet was more expensive than the recommended diet in all surveyed locations, regardless of the level of socioeconomic disadvantage or remoteness (Table 3B and 3C, Additional file 4).

Page $4 / 31$ 
Table 3

A Mean cost of current and recommended diets and component food groups, and affordability of the diets for the reference household per fortnight in Queensland

\begin{tabular}{|c|c|c|c|c|}
\hline \multirow[b]{3}{*}{ Food/food groups } & \multicolumn{4}{|c|}{ Total diet and food group costs } \\
\hline & \multicolumn{2}{|l|}{ Current diet } & \multicolumn{2}{|c|}{$\begin{array}{l}\text { Recommended (healthy, more equitable and } \\
\text { sustainable) diet }\end{array}$} \\
\hline & $\begin{array}{l}\text { Mean } \\
\text { cost } \pm \text { SD } \\
(A \$)\end{array}$ & $\begin{array}{l}\text { Proportion of } \\
\text { total cost (\%) }\end{array}$ & Mean cost $\pm S D(A \$)$ & $\begin{array}{l}\text { Proportion of total cost } \\
(\%)\end{array}$ \\
\hline Water, bottled & $\begin{array}{l}\$ 18.14 \pm \\
3.96\end{array}$ & $2 \%$ & $\$ 18.14 \pm 3.96$ & $3 \%$ \\
\hline Fruit & $\begin{array}{l}\$ 56.05 \pm \\
6.13\end{array}$ & $7 \%$ & $\$ 79.66 \pm 12.64$ & $12 \%$ \\
\hline Vegetables (\& legumes) & $\begin{array}{l}\$ 43.73 \pm \\
3.79\end{array}$ & $5 \%$ & $\$ 111.82 \pm 8.12$ & $17 \%$ \\
\hline Grain (cereal) foods & $\begin{array}{l}\$ 45.52 \pm \\
5.60\end{array}$ & $6 \%$ & $\$ 112.80 \pm 12.43$ & $18 \%$ \\
\hline Lean meats, poultry, fish, eggs, nuts, seeds \& alternatives & $\begin{array}{l}\$ 100.35 \pm \\
10.62\end{array}$ & $12 \%$ & $\$ 194.82 \pm 24.42$ & $30 \%$ \\
\hline Milk, yoghurt, cheese \& alternatives & $\begin{array}{l}\$ 50.49 \pm \\
7.23\end{array}$ & $6 \%$ & $\$ 118.31 \pm 18.57$ & $18 \%$ \\
\hline Unsaturated oils and spreads & $\begin{array}{l}\$ 1.28 \pm \\
0.17\end{array}$ & $<1 \%$ & $\$ 8.69 \pm 1.41$ & $1 \%$ \\
\hline Artificially sweetened beverages & $\begin{array}{l}\$ 5.99 \pm \\
1.22\end{array}$ & $1 \%$ & - & - \\
\hline Sugar sweetened beverages & $\begin{array}{l}\$ 31.96 \pm \\
5.91\end{array}$ & $4 \%$ & - & - \\
\hline Takeaway foods & $\begin{array}{l}\$ 160.37 \pm \\
33.18\end{array}$ & $20 \%$ & - & - \\
\hline Alcoholic beverages & $\begin{array}{l}\$ 96.56 \pm \\
6.63\end{array}$ & $12 \%$ & - & - \\
\hline All other discretionary choices & $\begin{array}{l}\$ 195.71 \pm \\
41.5\end{array}$ & $24 \%$ & - & - \\
\hline TOTAL diet & $\begin{array}{l}\$ 806.15 \pm \\
99.34\end{array}$ & $100 \%$ & $\$ 644.25 \pm 66.28$ & $100 \%$ \\
\hline Healthy foods and drinks & $\begin{array}{l}\$ 321.55 \pm \\
29.16\end{array}$ & $40 \%$ & $\$ 644.25 \pm 66.28$ & $100 \%$ \\
\hline \multirow[t]{2}{*}{ Discretionary foods and drinks } & $\begin{array}{l}\$ 484.60 \pm \\
71.93\end{array}$ & $60 \%$ & - & - \\
\hline & \multicolumn{4}{|c|}{ Income and diet affordability } \\
\hline Income categories & Income (A\$) & & $\begin{array}{l}\text { Current diet } \\
\text { affordability (\% of } \\
\text { income) }\end{array}$ & $\begin{array}{l}\text { Recommended diet } \\
\text { affordability (\% of } \\
\text { income) }\end{array}$ \\
\hline Median gross household income* & $\$ 3,011.55$ & & $29 \%$ & $23 \%$ \\
\hline Indicative low disposable household income & $\$ 2,358.33$ & & $34 \%$ & $27 \%$ \\
\hline $\begin{array}{l}\text { Indicative low disposable household income including government } \\
\text { supplements due to the SARS-CoV-2 pandemic }\end{array}$ & $\$ 3,336.02$ & & $24 \%$ & $19 \%$ \\
\hline
\end{tabular}


Table 3

B Cost of current and recommended diets and component food groups, and diet affordability for the reference household per fortnight, stratified by selected ar quintiles) in Queensland.

\begin{tabular}{|c|c|c|c|c|c|c|c|c|c|c|}
\hline \multirow{4}{*}{ 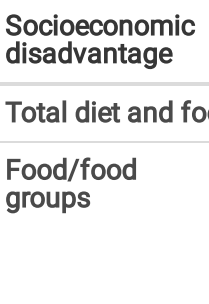 } & \multicolumn{4}{|c|}{ Least disadvantaged areas (SEIFA Quintile 5) } & \multicolumn{4}{|c|}{ Median disadvantaged areas (SEIFA Quintile 3) } & \multicolumn{2}{|c|}{ Most disadvanta } \\
\hline & d group cos & & & & & & & & & \\
\hline & \multicolumn{2}{|c|}{ Current diet } & \multicolumn{2}{|c|}{ Recommended diet } & \multicolumn{2}{|c|}{ Current diet } & \multicolumn{2}{|c|}{ Recommended diet } & \multicolumn{2}{|c|}{ Current diet } \\
\hline & $\begin{array}{l}\text { Mean } \\
\text { cost } \pm \\
\text { SD (AS) }\end{array}$ & $\begin{array}{l}\text { Proportion } \\
\text { of total } \\
\text { cost (\%) }\end{array}$ & $\begin{array}{l}\text { Mean cost } \\
\pm \text { SD (AS) }\end{array}$ & $\begin{array}{l}\text { Proportion of } \\
\text { total cost (\%) }\end{array}$ & $\begin{array}{l}\text { Mean } \\
\text { cost } \pm \\
\text { SD (AS) }\end{array}$ & $\begin{array}{l}\text { Proportion } \\
\text { of total } \\
\text { cost (\%) }\end{array}$ & $\begin{array}{l}\text { Mean cost } \\
\pm \text { SD (AS) }\end{array}$ & $\begin{array}{l}\text { Proportion of } \\
\text { total cost (\%) }\end{array}$ & $\begin{array}{l}\text { Mean } \\
\text { cost } \pm \\
\text { SD (AS) }\end{array}$ & $\begin{array}{l}\text { Prop } \\
\text { of to } \\
\text { cost }\end{array}$ \\
\hline Water, bottled & $\begin{array}{l}\$ 19.84 \\
\pm 0.51\end{array}$ & $3 \%$ & $\begin{array}{l}\$ 19.84 \pm \\
0.51\end{array}$ & $3 \%$ & $\begin{array}{l}\$ 19.07 \\
\pm 1.59\end{array}$ & $2 \%$ & $\begin{array}{l}\$ 19.07 \pm \\
1.59\end{array}$ & $3 \%$ & $\begin{array}{l}\$ 15.91 \\
\pm 5.77\end{array}$ & $2 \%$ \\
\hline Fruit & $\begin{array}{l}\$ 54.73 \\
\pm 5.12\end{array}$ & $7 \%$ & $\begin{array}{l}\$ 76.03 \pm \\
10.72\end{array}$ & $12 \%$ & $\begin{array}{l}\$ 56.45 \\
\pm 7.60\end{array}$ & $7 \%$ & $\begin{array}{l}\$ 81.83 \pm \\
13.71\end{array}$ & $13 \%$ & $\begin{array}{l}\$ 56.48 \\
\pm 4.47\end{array}$ & $7 \%$ \\
\hline $\begin{array}{l}\text { Vegetables (\& } \\
\text { legumes) }\end{array}$ & $\begin{array}{l}\$ 42.45 \\
\pm 4.09\end{array}$ & $5 \%$ & $\begin{array}{l}\$ 110.45 \pm \\
6.33\end{array}$ & $18 \%$ & $\begin{array}{l}\$ 44.81 \\
\pm 4.09\end{array}$ & $5 \%$ & $\begin{array}{l}\$ 112.86 \pm \\
10.85\end{array}$ & $18 \%$ & $\begin{array}{l}\$ 43.33 \\
\pm 2.74\end{array}$ & $5 \%$ \\
\hline $\begin{array}{l}\text { Grain (cereal) } \\
\text { foods }\end{array}$ & $\begin{array}{l}\$ 44.17 \\
\pm 4.36\end{array}$ & $6 \%$ & $\begin{array}{l}\$ 108.41 \pm \\
5.61\end{array}$ & $17 \%$ & $\begin{array}{l}\$ 45.95 \\
\pm 3.76\end{array}$ & $6 \%$ & $\begin{array}{l}\$ 113.79 \pm \\
9.12\end{array}$ & $18 \%$ & $\begin{array}{l}\$ 45.91 \\
\pm 7.63\end{array}$ & $6 \%$ \\
\hline $\begin{array}{l}\text { Lean meats, } \\
\text { poultry, fish, } \\
\text { eggs, nuts, } \\
\text { seeds \& } \\
\text { alternatives }\end{array}$ & $\begin{array}{l}\$ 95.14 \\
\pm 4.04\end{array}$ & $12 \%$ & $\begin{array}{l}\$ 185.84 \pm \\
9.93\end{array}$ & $30 \%$ & $\begin{array}{l}\$ 99.91 \\
\pm 8.21\end{array}$ & $12 \%$ & $\begin{array}{l}\$ 192.21 \pm \\
17.52\end{array}$ & $30 \%$ & $\begin{array}{l}\$ 104.33 \\
\pm 13.99\end{array}$ & $13 \%$ \\
\hline $\begin{array}{l}\text { Milk, yoghurt, } \\
\text { cheese \& } \\
\text { alternatives }\end{array}$ & $\begin{array}{l}\$ 49.41 \\
\pm 1.96\end{array}$ & $6 \%$ & $\begin{array}{l}\$ 118.99 \pm \\
8.95\end{array}$ & $19 \%$ & $\begin{array}{l}\$ 48.45 \\
\pm 4.90\end{array}$ & $6 \%$ & $\begin{array}{l}\$ 113.44 \pm \\
10.97\end{array}$ & $18 \%$ & $\begin{array}{l}\$ 53.60 \\
\pm 10.11\end{array}$ & $7 \%$ \\
\hline $\begin{array}{l}\text { Unsaturated } \\
\text { oils and } \\
\text { spreads }\end{array}$ & $\begin{array}{l}\$ 1.26 \pm \\
0.14\end{array}$ & $<1 \%$ & $\$ 8.21 \pm 0.77$ & $1 \%$ & $\begin{array}{l}\$ 1.27 \pm \\
0.14\end{array}$ & $<1 \%$ & $\$ 8.85 \pm 1.02$ & $1 \%$ & $\begin{array}{l}\$ 1.31 \pm \\
0.21\end{array}$ & $<1 \%$ \\
\hline $\begin{array}{l}\text { Artificially } \\
\text { sweetened } \\
\text { beverages }\end{array}$ & $\begin{array}{l}\$ 5.53 \pm \\
14.74\end{array}$ & $1 \%$ & - & - & $\begin{array}{l}\$ 5.96 \pm \\
27.55\end{array}$ & $1 \%$ & - & - & $\begin{array}{l}\$ 6.33 \pm \\
35.95\end{array}$ & $1 \%$ \\
\hline $\begin{array}{l}\text { Sugar } \\
\text { sweetened } \\
\text { beverages }\end{array}$ & $\begin{array}{l}\$ 29.89 \\
\pm 2.52\end{array}$ & $4 \%$ & - & - & $\begin{array}{l}\$ 31.54 \\
\pm 3.96\end{array}$ & $4 \%$ & - & - & $\begin{array}{l}\$ 33.82 \\
\pm 8.37\end{array}$ & $4 \%$ \\
\hline $\begin{array}{l}\text { Takeaway } \\
\text { foods }\end{array}$ & $\begin{array}{l}\$ 156.94 \\
\pm 5.36\end{array}$ & $20 \%$ & - & - & $\begin{array}{l}\$ 168.80 \\
\pm 1.80\end{array}$ & $21 \%$ & - & - & $\begin{array}{l}\$ 152.83 \\
\pm 9.35\end{array}$ & $19 \%$ \\
\hline $\begin{array}{l}\text { Alcoholic } \\
\text { beverages }\end{array}$ & $\begin{array}{l}\$ 97.30 \\
\pm 7.94\end{array}$ & $13 \%$ & - & - & $\begin{array}{l}\$ 98.66 \\
\pm 66.49\end{array}$ & $12 \%$ & - & - & $\begin{array}{l}\$ 93.62 \\
\pm 102.02\end{array}$ & $12 \%$ \\
\hline $\begin{array}{l}\text { All other } \\
\text { discretionary } \\
\text { choices }\end{array}$ & $\begin{array}{l}\$ 181.58 \\
\pm 11.51\end{array}$ & $23 \%$ & - & - & $\begin{array}{l}\$ 198.41 \\
\pm 40.49\end{array}$ & $24 \%$ & - & - & $\begin{array}{l}\$ 201.97 \\
\pm 51.95\end{array}$ & $25 \%$ \\
\hline TOTAL diet & $\begin{array}{l}\$ 778.25 \\
\pm 136.99\end{array}$ & $100 \%$ & $\begin{array}{l}\$ 627.77 \pm \\
27.91\end{array}$ & $100 \%$ & $\begin{array}{l}\$ 819.28 \\
\pm 93.16\end{array}$ & $100 \%$ & $\begin{array}{l}\$ 642.04 \pm \\
60.41\end{array}$ & $100 \%$ & $\begin{array}{l}\$ 809.43 \\
\pm 130.17\end{array}$ & $100 \%$ \\
\hline $\begin{array}{l}\text { Healthy foods } \\
\text { and drinks }\end{array}$ & $\begin{array}{l}\$ 312.54 \\
\pm 14.74\end{array}$ & $40 \%$ & $\begin{array}{l}\$ 627.77 \pm \\
27.91\end{array}$ & $100 \%$ & $\begin{array}{l}\$ 321.87 \\
\pm 27.55\end{array}$ & $39 \%$ & $\begin{array}{l}\$ 642.04 \pm \\
60.41\end{array}$ & $100 \%$ & $\begin{array}{l}\$ 327.20 \\
\pm 35.95\end{array}$ & $40 \%$ \\
\hline $\begin{array}{l}\text { Discretionary } \\
\text { foods and } \\
\text { drinks }\end{array}$ & $\begin{array}{l}\$ 465.72 \\
\pm 5.46\end{array}$ & $60 \%$ & - & - & $\begin{array}{l}\$ 497.41 \\
\pm 66.4\end{array}$ & $61 \%$ & - & - & $\begin{array}{l}\$ 482.23 \\
\pm 95.20\end{array}$ & $60 \%$ \\
\hline \multicolumn{11}{|c|}{ Income and diet affordability } \\
\hline $\begin{array}{l}\text { Income } \\
\text { categories }\end{array}$ & \multicolumn{2}{|c|}{ Income (A\$) } & $\begin{array}{l}\text { Current diet } \\
\text { affordability } \\
\text { (\% of } \\
\text { income) }\end{array}$ & $\begin{array}{l}\text { Recommended } \\
\text { diet } \\
\text { affordability } \\
\text { (\% of income) }\end{array}$ & \multicolumn{2}{|c|}{ Income (A\$) } & $\begin{array}{l}\text { Current diet } \\
\text { affordability } \\
\text { (\% of } \\
\text { income) }\end{array}$ & $\begin{array}{l}\text { Recommended } \\
\text { diet } \\
\text { affordability } \\
\text { (\% of income) }\end{array}$ & \multicolumn{2}{|c|}{ Income (A\$) } \\
\hline $\begin{array}{l}\text { Median gross } \\
\text { household } \\
\text { income* }\end{array}$ & \multicolumn{2}{|l|}{$\$ 4,241.61$} & $18 \%$ & $15 \%$ & \multicolumn{2}{|l|}{$\$ 3,040.52$} & $27 \%$ & $21 \%$ & \multicolumn{2}{|l|}{$\$ 2,157.72$} \\
\hline $\begin{array}{l}\text { Indicative low } \\
\text { disposable } \\
\text { household } \\
\text { income }\end{array}$ & \multicolumn{2}{|l|}{$\$ 2,358.33$} & $33 \%$ & $27 \%$ & \multicolumn{2}{|l|}{$\$ 2,358.33$} & $35 \%$ & $27 \%$ & \multicolumn{2}{|l|}{$\$ 2,358.33$} \\
\hline
\end{tabular}




\begin{tabular}{|c|c|c|c|c|c|c|c|}
\hline \multirow{2}{*}{$\begin{array}{l}\text { Socioeconomic } \\
\text { disadvantage }\end{array}$} & \multicolumn{3}{|c|}{ Least disadvantaged areas (SEIFA Quintile 5) } & \multicolumn{3}{|c|}{ Median disadvantaged areas (SEIFA Quintile 3) } & \multirow{2}{*}{$\begin{array}{l}\text { Most disadvanta } \\
\$ 3,336.02\end{array}$} \\
\hline & $\$ 3,336.02$ & $23 \%$ & $19 \%$ & $\$ 3,336.02$ & $25 \%$ & $19 \%$ & \\
\hline
\end{tabular}


Table 3

C Cost of current and recommended diets and component food groups, and diet affordability for the reference household per fortnight, stratified by selected re

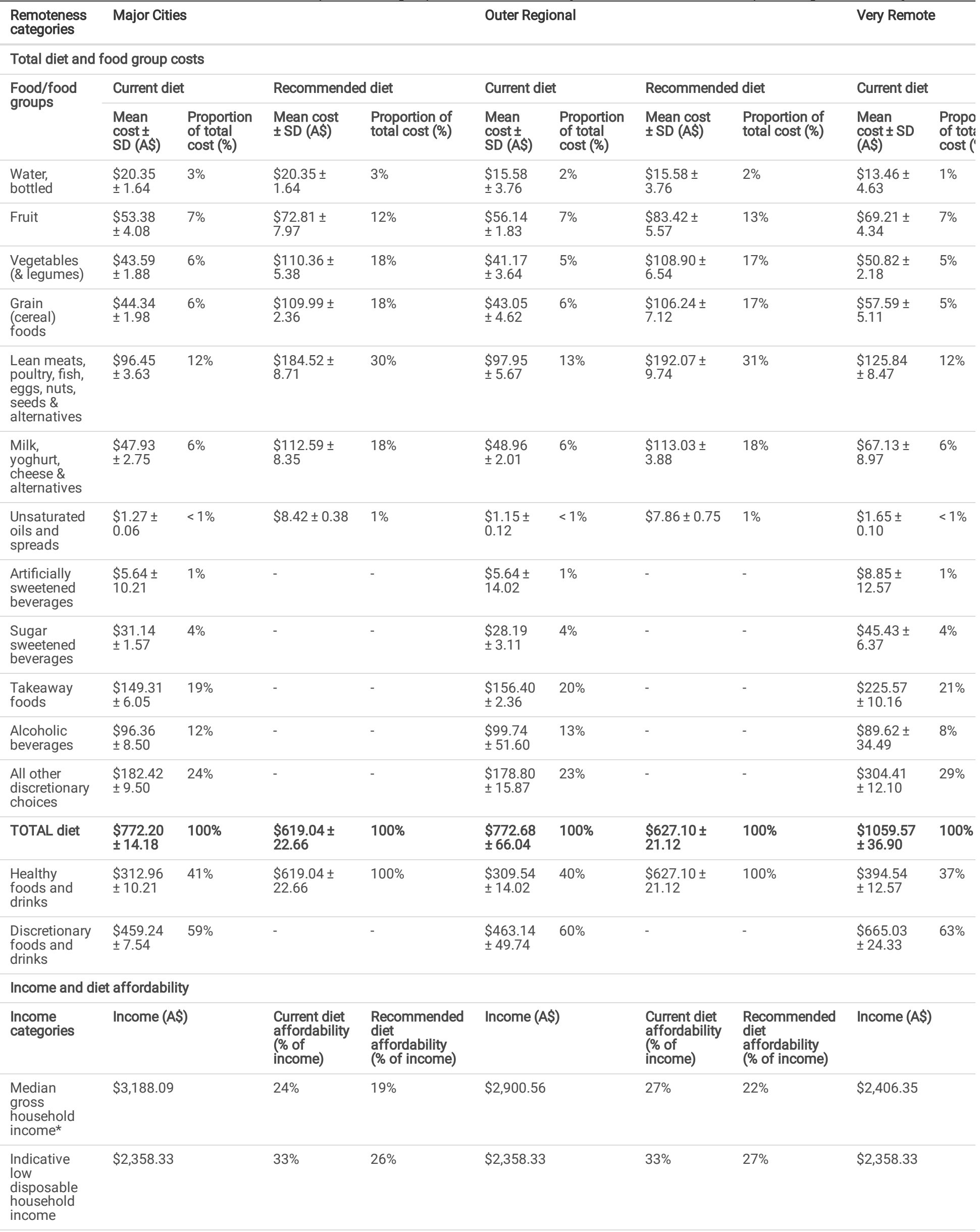




\begin{tabular}{|c|c|c|c|c|c|c|c|}
\hline $\begin{array}{l}\text { Remoteness } \\
\text { categories }\end{array}$ & Major Cities & & & Outer Regio & & & Very Remote \\
\hline $\begin{array}{l}\text { Indicative } \\
\text { low } \\
\text { disposable } \\
\text { household } \\
\text { income } \\
\text { including } \\
\text { government } \\
\text { supplements } \\
\text { due to the } \\
\text { SARS-CoV-2 } \\
\text { pandemic }\end{array}$ & $\$ 3,336.02$ & $23 \%$ & $19 \%$ & $\$ 3,336.02$ & $23 \%$ & $19 \%$ & $\$ 3,336.02$ \\
\hline
\end{tabular}

In all locations, discretionary foods and drinks comprised approximately $60 \%$ of the food budget of the reference household, with the remaining $40 \%$ covering the cost of healthy foods and drinks (Table $3 \mathrm{~A}$ ). Takeaway foods comprised $20 \%$, alcoholic drinks $12 \%$, and sugar sweetened beverages (SSBs) $4 \%$ of the current diet cost (Table 3A).

Figures 1A and 1B summarise the mean and component costs of the current and recommended diets, by area of socioeconomic disadvantage and remoteness categories respectively. The costs of the current and recommended diets by area of socioeconomic disadvantage and remoteness combined are shown in Figure 2.

The current diet was most expensive per fortnight in the median disadvantaged areas (A\$819.28 \pm 93.16$)$, followed by the most disadvantaged areas

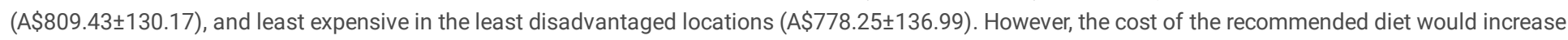
by five percent linearly from the least disadvantaged (A\$627.77 \pm 27.91 per fortnight) to the most disadvantaged areas (A\$657.83 \pm 85.44 per fortnight) (Figure $1 \mathrm{~A}$, Table 3B). The cost differential between the current and recommended diet was highest $(22 \%)$ in the median disadvantaged locations, and $19 \%$ in both the least and most disadvantaged areas.

The costs of the current and recommended diets were similar in major cities and outer regional areas; however the costs of both were much higher in very remote areas in Queensland, 37\% and 31\% respectively (Fig. 1B, Table 3C). The highest cost differential between the current and recommended diet was $23 \%$ in the very remote areas. The differential was $20 \%$ in major cities and $19 \%$ in outer regional locations.

The proportion of cost of discretionary items was highest in very remote areas at $63 \%$ (A\$665.03 \pm 24.33 per fortnight) of the current expenditure on food and drinks (Fig. 1B, Table 3C).

The dominant effect of remoteness on diet cost is evident in Fig. 2. In the most socioeconomically disadvantaged areas, the costs of current and recommended diets per fortnight were 43\% (A\$329.22) and 38\% (A\$232.36) higher respectively in very remote locations than in major cities in Queensland.

\subsection{Affordability of current and recommended diets}

The affordability of current and recommended diets in Queensland, by area of socioeconomic disadvantage and by remoteness categories is detailed in Tables 3A, 3B, and 3C, respectively. Results for the latter two analyses are summarised in Fig. 3A and 3B.

On average in Queensland (mean diet affordability across the sample SA2 locations), $29 \%$ and $23 \%$ of the median gross household income was required to purchase the current diet and recommended diet respectively (Table 3A). For low income households in Queensland as a whole, the current diet was not affordable at $34 \%$ of disposable income, and the proportion of household income required to be spent on a recommended diet (27\%) would exceed the food stress threshold (Table 3A). The indicative low disposable household income in Queensland (the same in each location) was A\$2,358.33 per fortnight in June 2019. With the government supplements due to the SARS-CoV-2 pandemic this increased to A\$3.336.02 per fortnight between May and September 2020, increasing affordability of recommended diets by $29 \%$ (Table $3 \mathrm{~A})$.

The current diet was unaffordable for households with low incomes in all socioeconomic areas assessed, costing 33-35\% of disposable income (Fig. 3A, Table 3B). Affordability of the recommended diet (27-28\%) would exceed the food stress threshold for low income families in all socioeconomic areas assessed (Fig. 3A, Table 3B).

In the most disadvantaged areas, the current and recommended diets were unaffordable at $38 \%$ and $30 \%$ of the median gross household income respectively (Fig. 3A, Table 3B). In the least disadvantaged areas, both the current and recommended diets were much more affordable, at $18 \%$ and $15 \%$ of median gross household income respectively (Fig. 3A, Table 3B). Surprisingly, the median gross household income was less than the indicative low disposable household income in the areas of most socioeconomic disadvantage (Table 3B).

Both current and recommended diets were least affordable for families living in very remote areas in Queensland (Fig. 3B, Table 3C). In very remote areas, the current diet cost $44 \%$ of total income of families with median gross household income; this proportion would be $34 \%$ for the recommended diet (Fig. $3 B$, Table 3 C). In contrast, in major cities, the current diet cost $24 \%$ of median gross household income, while the recommended diet would cost $19 \%$ of this (Fig. 3B, Table 3C).

In very remote areas, both diets were even less affordable for families with the indicative low disposable household income, for whom the current diet cost $45 \%$ of their income, and the recommended diet would cost 34\% (Fig. 3B, Table 3C). In major cities, the current diet cost 33\% while the recommended diet

Page $9 / 31$ 
would cost $26 \%$, of the disposable income of low income households (Fig. 3B, Table 3C).

Under the welfare policy settings in place from May 2020 to September 2020 in response to the SARS-CoV-2 pandemic, recommended diets would be more affordable for Queensland households eligible for additional benefits than they were before the pandemic (Table 3A). The proportion of disposable household income needed for the reference household to purchase a recommended diet reduced from 27-19\% (Table 3A), improving affordability of a healthy, more equitable and sustainable diet by around $29 \%$, with similar findings in all areas of socioeconomic disadvantage (Table 3B, Fig. 3A) and remoteness (Table 3C, Fig. 3B).

\section{Discussion}

\subsection{Methodological considerations}

For the first time, this study applied the Healthy Diets ASAP methods protocol to assess and compare the cost, cost differentials and affordability of current and recommended diets across locations stratified by area of socioeconomic disadvantage and remoteness in Queensland, Australia. Previously there had been no such systematic assessment of cost and affordability of diets using standardised methods throughout the state. Hence, these are the first results that can be compared to other survey findings and used to inform potential policy responses to help improve population diet.

Queensland was one of the first jurisdictions in Australia to report regularly on food prices from a public health perspective, through Healthy Food Access Basket surveys $(32,33)$. However, the 'healthy basket' diet pricing tool used until 2014 did not align with the ADGs as, while the diet was healthier than usual diets, it included items that were not recommended by the ADGs at the time, such as sugar, sausages, cake, and chocolate (20). Further, the cost of the current diet was not assessed for comparison, and determination of household income lacked rigour and consistency (20). Methodological differences in other jurisdictions made comparison of results difficult; these included variations in the composition of reference households, the included food items, calculation of household income, protocol of store sampling, and data collection (20).

\subsection{Diet costs}

The finding that recommended diets would be $20 \%$ less expensive than current diets in all surveyed locations in Queensland aligns with results of other studies that have used the Healthy Diets ASAP methods - in Canberra and Sydney $(34)$, country Victoria $(35)$, Brisbane $(8,19)$, in remote Aboriginal communities (36) and, using streamlined methods, nationally (37). These studies confirm that current diets cost 14-23\% more than recommended diets under current Australian policy settings, which include the exemption of basic healthy foods from 10\% Goods and Service Tax (GST) (38). Results are also consistent with those of a similar study in New Zealand (39), and related studies in the Northern Territory of Australia (40,41), and in one supermarket chain in Australia (13). However, the findings contradict the result of an earlier study conducted in Greater Western Sydney, which included fewer food items and focused on sustainability (15). A previous international systematic review and meta-analysis (which did not include Australian studies) (42), also found that healthy diets were more expensive than less healthy options - although only by US\$1.48/day. As with Barosh et al. (15), most included studies did not include alcohol in the current diet, potentially missing substantial costs (e.g. $12 \%$ of the total diet in the current study). Many food and diet pricing studies, including a recent Belgian study assessing costs of diets based on proportion of ultra-processed foods, measure costs per kcal or kJ, which can be methodologically spurious, conflating energy content and (high) energy density of unhealthy foods (43). Such studies confirm the need for standardised diet pricing methods (5, $9,20)$.

Other studies using the Healthy Diets ASAP method have found that food prices tend to be highest in the least socioeconomically disadvantaged areas (19, 34). However, this study has shown that, due to the confounding effect of remoteness, the recommended diet would be most expensive in the most disadvantaged locations. Diet costs increased markedly with remoteness, with total diet costs being $34 \%$ higher in very remote areas than in major cities. These results confirm the general findings of other studies (20), including in Queensland $(33,44)$, Western Australia (45), the Northern Territory (40, 46) and South Australia (17). A recent Inquiry into food pricing and food security in remote Indigenous communities by the Australian Parliament's Standing Committee on Indigenous Affairs (47) found that the relative high cost of food and drinks in very remote areas is the consequence of high freight, operational and maintenance costs; logistical challenges; and small populations of consumers, which limit stores' buying power. Other studies also suggest these higher prices are explained by the low density of food outlets in very remote communities, resulting in lack of competition (48). However, amenability of intervention in remote community stores, particularly those in discrete Aboriginal communities, is exemplified by implementation of store nutrition pricing policies, including cross-subsidisation of the price of healthy foods and drinks (Lee and Ride, 2018), which helps explain why the greatest cost differential between the current and recommended diet in this study $(23 \%)$ occurred in very remote areas.

\subsection{Drivers of food choice}

The finding that a reference family of two adults and two children spent $60 \%$ of their food budget on discretionary foods and drinks is similar to the results of previous studies using the Healthy Diets ASAP approach; these found discretionary items comprised around $58 \%$ of the current diet cost ( 8,34 ). This is also consistent with ADG Price Index (50) which used household expenditure data to show that discretionary items accounted for $58.2 \%$ of Australians' spending on food and drinks. The relative proportions of the food and drink budget that households spent on alcohol (12\%), take away meals (20\%), and SSBs (4\%) are similar to the proportions identified in previous studies in Sydney and Canberra (34).

This study showed that a transition from current to recommended diets would save Queensland families on average A\$161.90 per fortnight, yet the current diet reflects what the majority of Australians actually report eating. So why do people persist with their current diet if it is more expensive than a healthy, more equitable and sustainable diet? Although multiple scholars have argued that price is an important factor in consumer food choice $(5,51)$, this study's findings highlight that it is not the only key determinant. 
There is surprisingly little comprehensive research on the most influential drivers of consumer food choices. Multiple studies have cited the importance of particular determinants, such as taste $(53,54)$, healthiness/nutrition (55), time and convenience (Zorbas et al., 2018), gender (Vukmirovic, 2015),

psychological or behavioural factors (56), societal influence (53), accessibility (6), packaging and labelling (57, 58), advertising, marketing, and promotion (59, $60)$, availability $(6,56,61)$, and sociocultural acceptability (56). Food store practices, including placement of healthy and unhealthy products, the amount of shelf-space allocated to these (62), and promotions and pricing policies, such as subsidising fresh foods (Ferguson et al., 2018; Lee and Ride, 2018) have been cited as important factors in consumer food choice too. Some scholars consider that the perception that a healthy diet costs more than current diets is a contributing factor to food choice, especially in low income households (56).

Choice experiments aiming to rank drivers of food choice have returned conflicting results; however, these have been conducted in different groups, including from various countries, cultures, ages, and settings. Key factors identified included taste, nutrition, cost, and convenience (55, 65-67). However, the validity of the data in many self-reported studies is questionable, as social desirability may have influenced the participants' responses.

Growing evidence highlights the role of unhealthy commodity industries in driving dietary behaviours and food choice, through well-tested market and nonmarket activities that aim to increase the affordability, availability, accessibility, and acceptability of discretionary foods and drinks (68). The market activities of unhealthy commodity industries include building demand through advertising, marketing, and promotion practices, and by market expansion via trade and investment liberalisation (69). Non-market activities comprising corporate social and political activities aims to create a positive perception of the industry in the eyes of the public and policy makers, positioning industries to shape regulatory environments to benefit their profits (70). The growing economic power of these industries enhances their abilities to pursue such activities (68). As this study confirms, Australian households buying the current diet spent the bulk $(60 \%)$ of their food budget on discretionary foods and drinks. Hence commercial industries that produce, distribute and market these foods benefit from the status quo, and may actively seek to undermine efforts to improve Australian diets $(19,34,71)$.

\subsection{Diet affordability and food security}

This study demonstrates clearly that affordability of recommended diets is influenced by both food prices and household income. Hence low income families, especially those living in very remote areas where food prices are highest and household incomes are lowest, are most vulnerable to poor diets in Australia. The study found that recommended diets are unaffordable in very remote areas, but also showed that low income families are likely to be experiencing food stress irrespective of where they live in Queensland. This is an important finding given the established association between low socioeconomic factors and suboptimal diets $(12,72,73)$.

Diet affordability is a key component of food security. Food security is defined "when all people, at all times, have physical and economic access to sufficient, safe and nutritious food to meet their dietary needs and food preferences for an active and healthy life" (74). In Australia, when assessed by a lesser definition (i.e., as living in a household that ran out of food in the last 12 months and couldn't afford to buy more) $4 \%$ of Australians experienced food insecurity in the National Nutrition and Physical Activity Survey (NNPAS) 2011-13 (21). When more sensitive methods were used, 36\% of Australians were found to experience low food security (75). Another more recent study using the same methods as the NNPAS (2011-13) found $80 \%$ of Australian households receiving welfare support experienced food insecurity (76). Such results highlight the inadequacy of welfare payments, which need to be increased (77). Our study demonstrates that the government supplements introduced due to the SARS-CoV-2 pandemic improved the affordability of recommended diets for vulnerable families by $29 \%$. A recent Australian survey found that following the implementation of the supplements, $83 \%$ of welfare-dependent people reported eating healthier and more regularly than they did before the pandemic (78). These findings are consistent with the positive outcomes of evaluations of food voucher subsidy programs in the USA $(79,80)$.

The finding that the indicative low disposable household income was higher than the median gross household income in the areas of most socioeconomic disadvantage in Queensland may reflect that a high proportion of households in those locations rely solely on welfare income (e.g. aged pension or unemployment benefits) and/or on a single incomes (e.g. single parent families or single aged pensioners). These households would receive an income lower than the indicative low disposable household income used in this study. Hence, this study presents the best-case scenario for the most vulnerable households.

\subsection{Recommendations}

Despite growing evidence that the recommended diet would be more affordable than the current diet in Queensland and Australia, households consume the latter. Therefore, it is important to address environmental factors influencing dietary choices, including food prices.

1. The affordability of recommended diets should be protected through pricing and taxation policies, including retention of the exemption of basic healthy foods from GST in Australia. However, the results of the study suggest that the $10 \%$ tax differential may not be great enough to encourage consumption of recommended diets, consistent with evidence of the benefits of increasing taxation on specific unhealthy foods and drinks (e.g. SSBs) by $20 \%$ (81). Therefore it is recommended that GST on all unhealthy foods and drinks in Australia should be increased to $20 \%$, as supported by previous modelling (8).

2. Welfare benefits should be increased permanently beyond pre-pandemic levels to at least the levels assessed in this study (73), as advocated by the Australian Council of Social Service (82).

3. Action on the social and commercial determinants of diet and health is required, including key policy actions on regulation of advertising, marketing, and promotion activities of unhealthy food and alcohol industries (68) and in-store nutrition policies, such as allocating more shelf-space for healthy foods than discretionary items, and replacing the latter with healthy items at checkouts and end-of-aisle displays (83).

4. This study offers useful insights into the economic inequities in accessing healthy food and drinks in rural Australia (84), but further diet costing studies are required in remote Aboriginal communities, specifically $(36,47)$. Improving nutrition and health requires a genuine commitment to improving food 
security through reform that ensures Aboriginal and Torres Strait Islander people are the decision-makers to address the required structural and systemic changes (85).

5. There is a need to better investigate systematically the many factors affecting affordability, availability, accessibility, and acceptability of healthy foods, and thus better understand the drivers of food choice and barriers to food security, in Australia.

6. A national nutrition benchmarking, monitoring and reporting system, including diet cost and affordability, is needed urgently in Australia, to better understand the risk of food insecurity including the increasing risk related to the SARS-CoV-2 pandemic $(86,87)$ and climate change $(88)$.

\section{Limitations}

The methodological limitations of the Healthy Diets ASAP approach have been described previously $(8,19,34)$. While the indicative low income was calculated to reflect the reference household's disposable income, the median gross income values reflect the pre-tax income. Because of this limitation, diets may be even less affordable for families with median gross household income, than suggested.

Data on food and drink prices in early and mid-2020, which could not be collected because of SARS-CoV-2-related restrictions, would have assisted further analysis of the impact of the government supplements in low income households. However, lack of these data does not change the applicability of key findings - increasing welfare income has the potential to significantly increase affordability of recommended diets. Lessening of restrictions did enable food price data collection in stores in August/September 2020; this report is forthcoming.

The randomly selected SA2 locations included only one very remote location in an area of most disadvantage; inclusion of more very remote locations may be necessary to better understand the role of diet cost and affordability on consumer food choices in very remote communities.

\section{Conclusions}

This study highlighted the value of assessing the cost, cost differentials and affordability of current (unhealthy) and recommended (healthy, more equitable and sustainable) diets in the state of Queensland, Australia, by area of socioeconomic disadvantage and by remoteness. It showed that, although recommended diets can be less expensive than current diets, they are still unaffordable for low income households, particularly those living in very remote communities. The study highlights the need for more systematic research on the drivers of food choice, especially in vulnerable groups. The findings inform several recommendations for policy actions to improve food environments and food security. These include: maintaining exemption of basic healthy foods from GST and increasing the rate of GST on all discretionary food and drinks to $20 \%$; supporting the development and implementation of a regular, comprehensive, food and nutrition monitoring and surveillance program in Australia that includes assessment of the cost, cost differentials and affordability of current and recommended diets for key population sub-groups; and supplementing incomes of vulnerable households, especially in remote areas, to help improve diet equity and sustainability, and health and wellbeing for all.

\section{Abbreviations}

ABS Australian Bureau of Statistics

ADGs Australian Dietary Guidelines

ARIA+ Accessibility/Remoteness Index of Australia Plus

GST Goods and Services Tax

Healthy Diet ASAP methods protocol Healthy Diets Australian Standardised Affordability and Pricing methods protocol

INFORMAS International Network on Food and Obesity/Noncommunicable disease Research, Monitoring and Action Support

IRDS Index of Relative Socioeconomic Disadvantage

NCD Noncommunicable disease

SA2 Statistical Area Level 2

SEIFA Socio-Economic Indexes for Areas

SSBs sugar sweetened beverages

\section{Declarations}

\section{Ethics approval, consent to participate and for publication}

The University of Queensland Research Ethics Committee assessed this study as meeting the conditions for exemption from Human Research Ethics Committee review and approval in accordance with section 5.1.22 of the National Statement on Ethical Conduct in Human Research (2007). The Ethics Clearance number is 2019000849 . All data were obtained from publicly available sources and did not involve human participants. 
The datasets supporting the conclusions of this article are included within the article and its following additional files.

Additional file 1.doc: Details of the current and recommended diets

Additional file 2.doc: Calculations of indicative low disposable household incomes

Additional file 3.doc: Healthy Diets ASAP Survey Form

Additional file 4.doc: Cost and affordability of the current and recommended diets in the sampled locations

\section{Competing interests}

The authors declare that they have no competing interests.

\section{Funding}

Funding for this research was provided from the Australian Government's Medical Research Future Fund (MRFF). The MRFF provides funding to support health and medical research innovation, with the objective of improving the health and wellbeing of Australians. MRFF funding has been provided through The Australian Prevention Partnership Centre under the MRFF Boosting Preventive Health Research Program. Further information on the MRFF is available at www.health.gov.au/mrff.

\section{Authors' contributions}

AL: concept, sampling, project management, interpretation of results, and finalising manuscript

DP: data analysis, drafting tables, figures, and manuscript

LMH: data collection, analysis, drafting manuscript

$\mathrm{EPH}$ : data collection, analysis

ML: sampling, data collection, analysis, interpretation of results

\section{Acknowledgements}

Thank you to the members and staff of the Queensland Country Women's Association and the volunteer dietitians who helped to collect food and drink price data in the field.

\section{References}

1. GBD 2017 Diet Collaborators. Health effects of dietary risks in 195 countries, 1990-2017: a systematic analysis for the Global Burden of Disease Study 2017. The Lancet. 2017;393:1958-72.

2. GBD 2019 Risk Factors Collaborators. Global burden of 87 risk factors in 204 countries and territories, 1990-2019: a systematic analysis for the Global Burden of Disease Study 2019. The Lancet. 2020 Oct 17;396(10258):1135-59.

3. Swinburn B, Sacks G, Vandevijvere S, Kumanyika S, Lobstein T, Neal B, et al. INFORMAS (International Network for Food and Obesity/non-communicable diseases Research, Monitoring and Action Support): overview and key principles. Obesity reviews. 2013;14(S1):1-12.

4. Swinburn B, Kraak V, Allender S, Atkins V, Baker P, Bogard JR, et al. The Global Syndemic of Obesity, Undernutrition, and Climate Change: The Lancet Commission report. The Lancet. 2019;393(10173):791-846.

5. Lee A, Mhurchu CN, Sacks G, Swinburn B, Snowdon W, Vandevijvere S, et al. Monitoring the price and affordability of foods and diets globally: Monitoring food prices. Obesity Reviews. 2013 Oct;14:82-95.

6. Pitt E, Gallegos D, Comans T, Cameron C, Thornton L. Exploring the influence of local food environments on food behaviours: a systematic review of qualitative literature. Public Health Nutrition. 2017 Sep;20(13):2393-405.

7. Burns C, Friel S. It's time to determine the cost of a healthy diet in Australia. Australian and New Zealand Journal of Public Health. 2007;31(4):363-5.

8. Lee A, Kane S, Ramsey R, Good E, Dick M. Testing the price and affordability of healthy and current (unhealthy) diets and the potential impacts of policy change in Australia. BMC Public Health [Internet]. 2016 Dec [cited 2020 Apr 29];16(1). Available from:

http://bmcpublichealth.biomedcentral.com/articles/10.1186/s12889-016-2996-y

9. Seal J. Monitoring the price and availability of healthy food - time for a national approach. Nutrition \& Dietetics. 2004;61(4):197-8.

10. ABS. Overweight and obesity [Internet]. Canberra: Australian Bureau of Statistics (ABS); 2018 Dec. Available from:

https://www.abs.gov.au/statistics/health/health-conditions-and-risks/overweight-and-obesity/2017-18

11. Queensland Health. 2020 Chief Health Officer report [Internet]. State of Queensland; 2020. (Chief Health Officer reports). Available from: https://www.health.qld.gov.au/research-reports/reports/public-health/cho-report/current/full

12. NHMRC. Australian Dietary Guidelines [Internet]. National Health and Medical Research Council; 2013. Available from: https://www.eatforhealth.gov.au/sites/default/files/content/n55_australian_dietary_guidelines.pdf 
13. Goulding T, Lindberg R, Russell CG. The affordability of a healthy and sustainable diet: an Australian case study. Nutrition Journal [Internet]. 2020 Dec [cited 2020 Oct 29];19(1). Available from: https://nutritionj.biomedcentral.com/articles/10.1186/s12937-020-00606-Z

14. Hendrie G, Ridoutt B, Wiedmann T, Noakes M. Greenhouse Gas Emissions and the Australian Diet-Comparing Dietary Recommendations with Average Intakes. Nutrients. 2014 Jan 8;6(1):289-303.

15. Barosh L, Friel S, Engelhardt K, Chan L. The cost of a healthy and sustainable diet - who can afford it? 2014;(Journal Article).

16. Landrigan TJ, Kerr DA, Dhaliwal SS, Savage V, Pollard CM. Removing the Australian tax exemption on healthy food adds food stress to families vulnerable to poor nutrition. Aust N Z J Public Health. 2017 Dec;41(6):591-7.

17. Ward PR, Verity F, Carter P, Tsourtos G, Coveney J, Wong KC. Food Stress in Adelaide: The Relationship between Low Income and the Affordability of Healthy Food. Journal of environmental and public health. 2013;2013(Journal Article):968078-10.

18. The Treasury of the Australian Government. Economic Response to the Coronavirus [Internet]. The Treasury, Australian Government. 2020 [cited 2021 Feb 12]. Available from: https://treasury.gov.au/coronavirus

19. Lee A, Kane S, Lewis M, Good E, Pollard CM, Landrigan TJ, et al. Healthy diets ASAP - Australian Standardised Affordability and Pricing methods protocol. Nutrition Journal [Internet]. 2018 Dec [cited 2020 Apr 29];17(1). Available from: https://nutritionj.biomedcentral.com/articles/10.1186/s12937018-0396-0

20. Lewis M, Lee A. Costing 'healthy' food baskets in Australia - a systematic review of food price and affordability monitoring tools, protocols and methods. Public Health Nutrition. 2016;19(16):2872-86.

21. ABS. Australian Health Survey, National Health Survey, 2011-12 [Internet]. Canberra: Australian Bureau of Statistics (ABS); 2013. Available from: https://www.abs.gov.au/ausstats/abs@.nsf/Lookup/4324.0.55.001main+features12011-12

22. The Australian Prevention Partnership Centre. Supporting priority actions in the food and nutrition system [Internet]. The Australian Prevention Partnership Centre. 2021 [cited 2021 Feb 12]. Available from: https://preventioncentre.org.au/our-work/research-projects/supporting-priority-actions-in-the-food-andnutrition-system/\#progress

23. ABS. Statistical Area Level 2 (SA2). In: Australian Statistical Geography Standard (ASGS) [Internet]. Canberra: Australian Bureau of Statistics; 2016. Available from:

https://www.abs.gov.au/ausstats/abs@.nsf/Lookup/by\%20Subject/1270.0.55.001 July\%202016 Main\%20Features Statistical\%20Area\%20Level\%202

24. ABS. Socio-Economic Indexes for Areas [Internet]. Australian Bureau of Statistics. 2018. Available from: https://www.abs.gov.au/websitedbs/censushome.nsf/home/seifa

25. ABS. The Australian Statistical Geography Standard (ASGS) Remoteness Structure [Internet]. Australian Bureau of Statistics. 2020. Available from: https://www.abs.gov.au/websitedbs/d3310114.nsf/home/remoteness+structure

26. ABS. 2008.0 - Census of Population and Housing: Nature and Content, Australia, 2016 [Internet]. Canberra: ABS; 2016. Available from: https://www.abs.gov.au/AUSSTATS/abs@.nsf/Lookup/2008.0Main+Features922016?OpenDocument

27. ABS. 2016 Census Community Profiles [Internet]. Australian Bureau of Statistics. 2020. Available from: https://quickstats.censusdata.abs.gov.au/census_services/getproduct/census/2016/communityprofile/036?opendocument

28. ABS. Wage Price Index, Australia, June 2019 [Internet]. Australian Bureau of Statistics. 2019. Available from: https://www.abs.gov.au/statistics/economy/price-indexes-and-inflation/wage-price-index-australia/latest-release

29. The Australian Government. Services Australia [Internet]. 2020 [cited 2021 Feb 12]. Available from: https://www.servicesaustralia.gov.au/

30. CWA. Country Kitchens [Internet]. The Queensland Country Women's Association. 2020 [cited 2021 Feb 12]. Available from: https://www.qcwa.org.au/Country-Kitchens

31. Landrigan TJ, Kerr DA, Dhaliwal SS, Pollard CM. Protocol for the Development of a Food Stress Index to Identify Households Most at Risk of Food Insecurity in Western Australia. International journal of environmental research and public health. 2018 2019;16(1):79.

32. Queensland Health. The 2004 Healthy Food Access Basket (HFAB) Survey [Internet]. Queensland Health; 2004. (Healthy Food Access Basket Survey). Available from: https://www.health.qld.gov.au/_data/assets/pdf_file/0035/438695/30605.pdf

33. Queensland Health. The 2014 Healthy Food Access Basket (HFAB) Survey [Internet]. Brisbane: Queensland Government; 2015. Available from: https://www.health.qld.gov.au/research-reports/reports/public-health/food-nutrition/access/overview

34. Lee A, Kane S, Herron L-M, Matsuyama M, Lewis M. A tale of two cities: the cost, price-differential and affordability of current and healthy diets in Sydney and Canberra, Australia. International Journal of Behavioral Nutrition and Physical Activity [Internet]. 2020 Dec [cited 2020 Jul 8];17(1). Available from: https://ijbnpa.biomedcentral.com/articles/10.1186/s12966-020-00981-0

35. Love P, Whelan J, Bell C, Grainger F, Russell C, Lewis M, et al. Healthy Diets in Rural Victoria-Cheaper than Unhealthy Alternatives, Yet Unaffordable. International Journal of Environmental Research and Public Health. 2018 Nov 5;15(11):2469.

36. Lee A, Lewis M. Testing the Price of Healthy and Current Diets in Remote Aboriginal Communities to Improve Food Security: Development of the Aboriginal and Torres Strait Islander Healthy Diets ASAP (Australian Standardised Affordability and Pricing) Methods. International Journal of Environmental Research and Public Health. 2018 Dec 19;15(12):2912.

37. Zorbas C, Lee A, Peeters A, Lewis M, Landrigan T, Backholer K. Streamlined data-gathering techniques to estimate the price and affordability of healthy and unhealthy diets under different pricing scenarios. Public Health Nutrition. 2020;1-11.

38. Australian Government. Re:think; Better tax, better Australia [Internet]. Canberra: Department of the Treasury, Australia; 2015. Available from: https://apo.org.au/node/53883 
39. Mackay S, Buch T, Vandevijvere S, Goodwin R, Korohina E, Funaki-Tahifote M, et al. Cost and Affordability of Diets Modelled on Current Eating Patterns and on Dietary Guidelines, for New Zealand Total Population, Māori and Pacific Households. International Journal of Environmental Research and Public Health. 2018 Jun 13;15(6):1255.

40. Department of Health. Northern Territory Market Basket Survey 2017 [Internet]. Darwin: Northern Territory Government of Australia; 2017. Available from: https://hdl.handle.net/10137/7711

41. Department of Health. Northern Territory Market Basket Survey 2016 [Internet]. Darwin: Northern Territory Government of Australia; 2016. Available from: http://hdl.handle.net/10137/1428

42. Rao M, Afshin A, Singh G, Mozaffarian D. Do healthier foods and diet patterns cost more than less healthy options? A systematic review and metaanalysis. BMJ Open. 2013;3(12):e004277.

43. Carlson A, Frazao E. Are Healthy Foods Really More Expensive? It Depends on How You Measure the Price. SSRN Electronic Journal [Internet]. 2012 [cited 2020 Jun 25]; Available from: http://www.ssrn.com/abstract=2199553

44. Harrison M, Lee A, Findlay M, Nicholls R, Leonard D, Martin C. The increasing cost of healthy food. Australian and New Zealand Journal of Public Health. 2010;34(2):179-86.

45. Pollard CM, Landrigan TJ, Ellies PL, Kerr DA, Underwood Lester ML, Goodchild SE. Geographic factors as determinants of food security: A Western Australian food pricing and quality study. Asia Pacific Journal of Clinical Nutrition. 2014;23(4):703-13.

46. Ferguson M, O'Dea K, Chatfield M, Moodie M, Altman J, Brimblecombe J. The comparative cost of food and beverages at remote Indigenous communities, Northern Territory, Australia. Australian and New Zealand Journal of Public Health. 2016 Apr;40(S1):S21-6.

47. House of Representatives Standing Committee on Indigenous Affairs. Report on food pricing and food security in remote Indigenous communities [Internet]. Canberra: The Parliament of Australia; 2020 Nov. Available from:

https://www.aph.gov.au/Parliamentary_Business/Committees/House/Indigenous_Affairs/Foodpricing/Report

48. Ghosh-Dastidar M, Hunter G, Collins RL, Zenk SN, Cummins S, Beckman R, et al. Does opening a supermarket in a food desert change the food environment? Health Place. 2017 Jul;46:249-56.

49. Lee A, Ride K. Review of nutrition among Aboriginal and Torres Strait Islander people. Australian Indigenous Health Bulletin [Internet]. 2018;18(1). Available from: http://healthbulletin.org.au/articles/review-of-nutrition-among-aboriginal-and-torres-strait-islander-people/

50. ABS. Australian Dietary Guidelines Price Indexes [Internet]. 2016. Available from: https://www.abs.gov.au/ausstats/abs@.nsf/Lookup/6401.0Feature+Article1Dec+2015

51. Cornelsen L, Green R, Turner R, Dangour AD, Shankar B, Mazzocchi M, et al. What Happens to Patterns of Food Consumption when Food Prices Change? Evidence from A Systematic Review and Meta-Analysis of Food Price Elasticities Globally. Health Economics. 2015 Dec;24(12):1548-59.

52. Bennett R, Zorbas C, Huse O, Peeters A, Cameron AJ, Sacks G, et al. Prevalence of healthy and unhealthy food and beverage price promotions and their potential influence on shopper purchasing behaviour: A systematic review of the literature. Obesity Reviews [Internet]. 2020 Jan [cited 2020 Nov 16];21(1). Available from: https://onlinelibrary.wiley.com/doi/abs/10.1111/obr.12948

53. Janssen HG, Davies IG, Richardson LD, Stevenson L. Determinants of takeaway and fast food consumption: a narrative review. Nutrition Research Reviews. 2018 Jun;31(1):16-34.

54. Liem DG, Russell CG. The Influence of Taste Liking on the Consumption of Nutrient Rich and Nutrient Poor Foods. Frontiers in Nutrition [Internet]. 2019 Nov 15 [cited 2020 Dec 13];6. Available from: https://www.frontiersin.org/article/10.3389/fnut.2019.00174/full

55. Kamphuis CBM, de Bekker-Grob EW, van Lenthe FJ. Factors affecting food choices of older adults from high and low socioeconomic groups: a discrete choice experiment. American Journal of Clinical Nutrition. 2015 Apr;101(4):768-74.

56. Zorbas C, Palermo C, Chung A, Iguacel I, Peeters A, Bennett R, et al. Factors perceived to influence healthy eating: a systematic review and metaethnographic synthesis of the literature. Nutrition Reviews [Internet]. 2018 Sep 7 [cited 2020 Dec 13]; Available from: https://academic.oup.com/nutritionreviews/advance-article/doi/10.1093/nutrit/nuy043/5092635

57. Daley AJ, McGee E, Bayliss S, Coombe A, Parretti HM. Effects of physical activity calorie equivalent food labelling to reduce food selection and consumption: systematic review and meta-analysis of randomised controlled studies. J Epidemiol Community Health. 2020 Mar;74(3):269-75.

58. Shangguan S, Afshin A, Shulkin M, Ma W, Marsden D, Smith J, et al. A Meta-Analysis of Food Labeling Effects on Consumer Diet Behaviors and Industry Practices. Am J Prev Med. 2019 Feb;56(2):300-14.

59. Boyland EJ, Nolan S, Kelly B, Tudur-Smith C, Jones A, Halford JC, et al. Advertising as a cue to consume: a systematic review and meta-analysis of the effects of acute exposure to unhealthy food and nonalcoholic beverage advertising on intake in children and adults. The American journal of clinical nutrition. 2016;103(2):519-33.

60. Vukmirovic M. The effects of food advertising on food-related behaviours and perceptions in adults: A review. Food Research International. 2015 Sep;75:13-9.

61. Hollands GJ, Carter P, Anwer S, King SE, Jebb SA, Ogilvie D, et al. Altering the availability or proximity of food, alcohol, and tobacco products to change their selection and consumption. Cochrane Public Health Group, editor. Cochrane Database of Systematic Reviews [Internet]. 2019 Sep 4 [cited 2020 Nov 17]; Available from: http://doi.wiley.com/10.1002/14651858.CD012573.pub3

62. Shaw SC, Ntani G, Baird J, Vogel CA. A systematic review of the influences of food store product placement on dietary-related outcomes. Nutrition Reviews [Internet]. 2020 Jun 1 [cited 2020 Nov 17]; Available from: https://academic.oup.com/nutritionreviews/advancearticle/doi/10.1093/nutrit/nuaa024/5850124 
63. Ferguson M, O'Dea K, Altman J, Moodie M, Brimblecombe J. Health-Promoting Food Pricing Policies and Decision-Making in Very Remote Aboriginal and Torres Strait Islander Community Stores in Australia. International Journal of Environmental Research and Public Health. 2018 Dec 19;15(12):2908.

64. Lee A, Ride K. Review of programs and services to improve Aboriginal and Torres Strait Islander nutrition and food security. Australian Indigenous Health Bulletin. 2018;18(4):24.

65. Aggarwal A, Rehm CD, Monsivais P, Drewnowski A. Importance of taste, nutrition, cost and convenience in relation to diet quality: Evidence of nutrition resilience among US adults using National Health and Nutrition Examination Survey (NHANES) 2007-2010. Preventive Medicine. 2016;90(Journal Article):184-92.

66. Bazzani C, Gustavsen GW, Nayga RM, Rickertsen K. A comparative study of food values between the United States and Norway. European Review of Agricultural Economics. 2018 Apr;45(2):239-72.

67. Kershaw KN, Klikuszowian E, Schrader L, Siddique J, Van Horn L, Womack VY, et al. Assessment of the influence of food attributes on meal choice selection by socioeconomic status and race/ethnicity among women living in Chicago, USA: A discrete choice experiment. Appetite. 2019 Aug 1;139:1925.

68. Buse K, Tanaka S, Hawkes S. Healthy people and healthy profits? Elaborating a conceptual framework for governing the commercial determinants of noncommunicable diseases and identifying options for reducing risk exposure. Globalization and Health [Internet]. 2017 Dec [cited 2018 Mar 23];13(1). Available from: http://globalizationandhealth.biomedcentral.com/articles/10.1186/s12992-017-0255-3

69. Baker P, Machado P, Santos T, Sievert K, Backholer K, Hadjikakou M, et al. Ultra-processed foods and the nutrition transition: Global, regional and national trends, food systems transformations and political economy drivers. Obesity Reviews [Internet]. 2020 Dec [cited 2020 Nov 17];21(12). Available from: https://onlinelibrary.wiley.com/doi/10.1111/obr.13126

70. Mellahi K, Frynas JG, Sun P, Siegel D. A Review of the Nonmarket Strategy Literature: Toward a Multi-Theoretical Integration. Journal of Management. 2016 Jan;42(1):143-73.

71. Lee A, Cullerton K, Herron L-M. Achieving Food System Transformation: Insights From A Retrospective Review of Nutrition Policy (In)Action in HighIncome Countries. Int J Health Policy Manag. 2020 Oct 19;1.

72. Livingstone KM, Olstad DL, Leech RM, Ball K, Meertens B, Potter J, et al. Socioeconomic Inequities in Diet Quality and Nutrient Intakes among Australian Adults: Findings from a Nationally Representative Cross-Sectional Study. Nutrients. 2017;9(10):1092.

73. Lewis M, Lee A. Dietary Inequity? A Systematic Scoping Review of Dietary Intake in Low Socioeconomic Groups compared to High Socioeconomic Groups in Australia. Public Health Nutrition. 2021;24(3):393-411.

74. FAO. Voluntary Guidelines to support the progressive realization of the right to adequate food in the context of national food security [Internet]. Rome: Food and Agriculture Organization of the United Nations (FAO); 2005. Available from: http://www.fao.org/3/y7937e/y7937e00.htm

75. Butcher LM, O'Sullivan TA, Ryan MM, Lo J, Devine A. Utilising a multi-item questionnaire to assess household food security in Australia. Health Promotion Journal of Australia. 2019 Jan;30(1):9-17.

76. Temple J, Booth S, Pollard C. Social Assistance Payments and Food Insecurity in Australia: Evidence from the Household Expenditure Survey. International Journal of Environmental Research and Public Health. 2019;16(3):455.

77. McKenzie HJ, McKay FH. Food as a discretionary item: the impact of welfare payment changes on low-income single mother's food choices and strategies. Journal of Poverty and Social Justice. 2017 Feb;25(1):35-48.

78. Australian Council of Social Science. Survey of 955 people receiving the new rate of jobseeker and other allowances Australian Council of Social Service. [Internet]. ACOSS; 2020. Available from: https://www.acoss.org.au/wp-content/uploads/2020/06/200624-I-Can-Finally-Eat-Fresh-Fruit-And-VegetablesResults-Of-The-Coronaviru....pdf

79. Durward CM, Savoie-Roskos M, Atoloye A, Isabella P, Jewkes MD, Ralls B, et al. Double Up Food Bucks Participation is Associated with Increased Fruit and Vegetable Consumption and Food Security Among Low-Income Adults. Journal of Nutrition Education and Behavior. 2019 Mar;51(3):342-7.

80. Sanjeevi N, Freeland-Graves JH, Sachdev PK, Sands J. Do food expenditure patterns of supplemental nutrition assistance program households meet thrifty food plan recommendations? Journal of Hunger \& Environmental Nutrition. 2019;14(3):352-64.

81. Thow AM, Downs S, Jan S. A systematic review of the effectiveness of food taxes and subsidies to improve diets: Understanding the recent evidence. Nutrition reviews. 2014;72(9):551-65.

82. Australian Council of Social Service. Faces of Unemployment 2020 [Internet]. 2020. Available from: https://www.acoss.org.au/faces-of-unemployment2020/

83. Sacks G, Grigsby-Duffy L, Robinson E, Orellana L, Cameron A. Inside our supermarkets: Assessment of the healthiness of Australian supermarkets, Australia 2020. [Internet]. Melbourne: Deakin University; 2020. Available from: https://www.insideourfoodcompanies.com.au/supermarkets

84. NRHA. Food security and health in rural and remote Australia [Internet]. Wagga Wagga, NSW: National Rural Health Alliance (NRHA). Rural Industries Research and Development Corporation.; 2016 [cited 2020 Jun 26]. Available from: https://rirdc.infoservices.com.au/items/16-053

85. Fredericks B, Bradfield A. Food insecurity in uncertain times. Ways forward post-pandemic. In: Remaking the Balance [Internet]. 71st ed. 2021. (Griffith Review). Available from: https://www.griffithreview.com/editions/remaking-the-balance/

86. Niles MT, Bertmann F, Belarmino EH, Wentworth T, Biehl E, Neff R. The Early Food Insecurity Impacts of COVID-19. Nutrients. 2020 Jul;12(7):2096.

87. Wolfson JA, Leung CW. Food Insecurity and COVID-19: Disparities in Early Effects for US Adults. Nutrients. 2020 Jun;12(6):1648.

88. Friel S. Climate change and the people's health: the need to exit the consumptagenic system. The Lancet. 2020;395(10225):666-8.

\section{Tables}




\section{Additional File 1}

Details of the current (unhealthy) and recommended (healthy, more equitable and sustainable) diets: total energy of food baskets representative household per day (kJ/day) and foods comprising diet baskets per representative household per fortnight. 


\begin{tabular}{|c|c|c|c|c|c|c|c|}
\hline & $\begin{array}{l}\text { Current } \\
\text { (unhealthy } \\
\text { diet) }\end{array}$ & $\begin{array}{l}\text { Recommended } \\
\text { (healthy, more } \\
\text { equitable and } \\
\text { sustainable) diet }\end{array}$ & & $\begin{array}{l}\text { Current } \\
\text { (unhealthy } \\
\text { diet) }\end{array}$ & $\begin{array}{l}\text { Recommended } \\
\text { (healthy, more } \\
\text { equitable and } \\
\text { sustainable) diet }\end{array}$ & & $\begin{array}{l}\text { Current } \\
\text { (unhealthy } \\
\text { diet) }\end{array}$ \\
\hline \multirow{4}{*}{$\begin{array}{l}\text { Total energy of } \\
\text { basket per day per } \\
\text { household }\end{array}$} & \multirow[t]{4}{*}{$\begin{array}{l}33860 \\
\mathrm{~kJ} / \text { day }\end{array}$} & \multirow[t]{4}{*}{33610 kj/day } & \multicolumn{3}{|l|}{$\begin{array}{l}\text { Grain (cereal) } \\
\text { foods }\end{array}$} & \multicolumn{2}{|l|}{$\begin{array}{l}\text { Discretionary } \\
\text { choices* }\end{array}$} \\
\hline & & & $\begin{array}{l}\text { Wholegrain cereal } \\
\text { biscuits, Weetbix }{ }^{\top M}\end{array}$ & 430 & 2216 & $\begin{array}{l}\text { Beer, full } \\
\text { strength (ml) }\end{array}$ & 4661 \\
\hline & & & $\begin{array}{l}\text { Wholemeal bread, } \\
\mathrm{pp}(\mathrm{g})\end{array}$ & 1054 & 4272 & $\begin{array}{l}\text { White wine, } \\
\text { sparkling (ml) }\end{array}$ & 863 \\
\hline & & & $\begin{array}{l}\text { Rolled oats, whole } \\
\text { (g) }\end{array}$ & 870 & 6648 & Whiskey (ml) & 266 \\
\hline \multicolumn{3}{|l|}{ Food (per fortnight) } & White bread, pp (g) & 3033 & 893 & Red wine (ml) & 1078 \\
\hline $\begin{array}{l}\text { Bottled water, still } \\
(\mathrm{ml})\end{array}$ & 5296 & 5296 & Cornflakes (g) & 680 & 670 & Butter (g) & 280 \\
\hline $\begin{array}{l}\text { Artificially } \\
\text { sweetened } \\
\text { beverages }\end{array}$ & 2391 & $\mathrm{~N} / \mathrm{A}$ & $\begin{array}{l}\text { White pasta, } \\
\text { spaghetti (g) }\end{array}$ & 1326 & 2042 & $\begin{array}{l}\text { Muffin, } \\
\text { commercial (g) }\end{array}$ & 1455 \\
\hline \multicolumn{3}{|l|}{$\begin{array}{l}\text { Core five food } \\
\text { groups }\end{array}$} & $\begin{array}{l}\text { White rice, medium } \\
\text { grain }(\mathrm{g})\end{array}$ & 1622 & 2042 & $\begin{array}{l}\text { Cream-filled } \\
\text { sweet biscuit, } \\
\text { pp (g) }\end{array}$ & 496 \\
\hline \multicolumn{3}{|l|}{ Fruit } & $\begin{array}{l}\text { Dry water cracker } \\
\text { biscuit }(\mathrm{g})\end{array}$ & 259 & 781 & $\begin{array}{l}\text { Muesli bar, pp } \\
(\mathrm{g})\end{array}$ & 373 \\
\hline $\begin{array}{l}\text { Apples, red, loose } \\
\text { (g) }\end{array}$ & 3497 & 5460 & $\begin{array}{l}\text { Bread in sandwich } \\
\text { (g) }\end{array}$ & 120 & 120 & $\begin{array}{l}\text { Mixed nuts, } \\
\text { salted (g) }\end{array}$ & 255 \\
\hline $\begin{array}{l}\text { Bananas, } \\
\text { Cavendish, loose } \\
\text { (g) }\end{array}$ & 899 & 5460 & \multicolumn{3}{|l|}{$\begin{array}{l}\text { Meats, poultry, fish, } \\
\text { eggs, nuts, seeds } \\
\text { and altematives }\end{array}$} & $\begin{array}{l}\text { Pizza, } \\
\text { commercial (g) }\end{array}$ & 1182 \\
\hline Oranges, loose (g) & 1664 & 5460 & Beef mice, lean (g) & 267 & 1168 & $\begin{array}{l}\text { Savoury } \\
\text { flavoured } \\
\text { biscuits (g) }\end{array}$ & 222 \\
\hline $\begin{array}{l}\text { Fruit salad, canned } \\
\text { in juice }(\mathrm{g})\end{array}$ & 2046 & N/A & $\begin{array}{l}\text { Lamb loin chops } \\
\text { (g) }\end{array}$ & 257 & 1169 & $\begin{array}{l}\text { Confectionary } \\
\text { (g) }\end{array}$ & 418 \\
\hline Fruit juice (ml) & 3026 & N/A & $\begin{array}{l}\text { Beef rump steak } \\
\text { (g) }\end{array}$ & 1056 & 1172 & Chocolate (g) & 441 \\
\hline \multicolumn{3}{|l|}{ Vegetables } & $\begin{array}{l}\text { Tuna, canned in } \\
\text { vegetable oil (g) }\end{array}$ & 1052 & 1841 & $\begin{array}{l}\text { Sugar } \\
\text { sweetened } \\
\text { beverages, } \\
\text { Coca Cola (ml) }\end{array}$ & 12012 \\
\hline $\begin{array}{l}\text { Potato, white, loose } \\
\text { (g) }\end{array}$ & 1460 & 2320 & $\begin{array}{l}\text { Whole barbecue } \\
\text { chicken, cooked (g) }\end{array}$ & 1661 & 1471 & $\begin{array}{l}\text { Meat pie, } \\
\text { commercial (g) }\end{array}$ & 1638 \\
\hline $\begin{array}{l}\text { Sweetcorn, canned, } \\
\text { no added salt (g) }\end{array}$ & 206 & 1160 & Eggs (g) & 872 & 2208 & $\begin{array}{l}\text { Frozen } \\
\text { lasagne, pp (g) }\end{array}$ & 4322 \\
\hline Broccoli, loose (g) & 422 & 1470 & $\begin{array}{l}\text { Meat in tinned } \\
\text { meat and } \\
\text { vegetable } \\
\text { casserole (g) }\end{array}$ & 646 & 780 & $\begin{array}{l}\text { Hamburger, } \\
\text { commercial (g) }\end{array}$ & 2413 \\
\hline $\begin{array}{l}\text { White cabbage, } \\
\text { loose }(\mathrm{g})\end{array}$ & 235 & 1470 & $\begin{array}{l}\text { Chicken in } \\
\text { sandwhich }\end{array}$ & 120 & 120 & $\begin{array}{l}\text { Beef sausages } \\
\text { (g) }\end{array}$ & 1048 \\
\hline $\begin{array}{l}\text { Iceberg lettuce, } \\
\text { whole }(\mathrm{g})\end{array}$ & 795 & 1470 & $\begin{array}{l}\text { Peanuts, roasted, } \\
\text { unsalted }\end{array}$ & N/A & 780 & $\operatorname{Ham}(\mathrm{g})$ & 189 \\
\hline Carrot, loose (g) & 753 & 2205 & \multicolumn{3}{|c|}{ Milk, yoghurt, cheese and alternatives } & $\begin{array}{l}\text { Potato crisps, } \\
\mathrm{pp}(\mathrm{g})\end{array}$ & 518 \\
\hline Pumpkin (g) & 240 & 2205 & $\begin{array}{l}\text { Cheddar cheese, } \\
\text { full fat }(\mathrm{g})\end{array}$ & 624 & 704 & $\begin{array}{l}\text { Potato chips, } \\
\text { hot, } \\
\text { commercial (g) }\end{array}$ & 670 \\
\hline $\begin{array}{l}\text { Four bean mix, } \\
\text { canned }(\mathrm{g})\end{array}$ & 74 & 1005 & $\begin{array}{l}\text { Cheddar cheese, } \\
\text { reduced fat (g) }\end{array}$ & 44 & 516 & Ice cream (g) & 1830 \\
\hline $\begin{array}{l}\text { Diced tomatoes, } \\
\text { canned in tomato }\end{array}$ & 234 & 1638 & Milk, full fat (g) & 5961 & 6438 & $\begin{array}{l}\text { White sugar } \\
\text { (g) }\end{array}$ & 564 \\
\hline
\end{tabular}




\begin{tabular}{|c|c|c|c|c|c|c|c|}
\hline $\begin{array}{l}\text { Onion, brown, loose } \\
\text { (g) }\end{array}$ & 84 & 1638 & $\begin{array}{l}\text { Milk, reduced fat } \\
(\mathrm{g})\end{array}$ & 2929 & 12000 & $\begin{array}{l}\text { Salad dressing } \\
(\mathrm{ml})\end{array}$ & 277 \\
\hline $\begin{array}{l}\text { Tomatoes, loose } \\
\text { (g) }\end{array}$ & 488 & 1638 & $\begin{array}{l}\text { Yoghurt, full fat, } \\
\text { plain }(\mathrm{g})\end{array}$ & 204 & 2576 & $\begin{array}{l}\text { Tomato sauce } \\
(\mathrm{ml})\end{array}$ & 569 \\
\hline $\begin{array}{l}\text { Frozen mixed } \\
\text { vegetables, pp (g) }\end{array}$ & 1184 & 1638 & $\begin{array}{l}\text { Yoghurt, reduced } \\
\text { fat, flavoured } \\
\text { (vanilla) (g) }\end{array}$ & 676 & 5100 & $\begin{array}{l}\text { Chicken soup, } \\
\text { canned (g) }\end{array}$ & 1340 \\
\hline Frozen peas, pp (g) & 273 & 1638 & Flavoured milk (ml) & 2416 & N/A & $\begin{array}{l}\text { Orange juice } \\
(\mathrm{ml})\end{array}$ & 3027 \\
\hline $\begin{array}{l}\text { Baked beans, } \\
\text { canned }(\mathrm{g})\end{array}$ & 369 & 1005 & $\begin{array}{l}\text { Unsaturated oils } \\
\text { and spreads }\end{array}$ & & & $\begin{array}{l}\text { Fish fillet } \\
\text { crumbed, pp } \\
\text { (g) }\end{array}$ & 302 \\
\hline $\begin{array}{l}\text { Salad vegetables in } \\
\text { sandwich }\end{array}$ & 120 & 120 & $\begin{array}{l}\text { Canola margarine } \\
\text { (g) }\end{array}$ & 170 & 412 & $\begin{array}{l}\text { Instant } \\
\text { noodles, wheat } \\
\text { based (g) }\end{array}$ & 381 \\
\hline \multirow{2}{*}{$\begin{array}{l}\text { Vegetables in } \\
\text { tinned meat and } \\
\text { vegetable casserole } \\
\text { (g) }\end{array}$} & \multirow[t]{2}{*}{646} & \multirow[t]{2}{*}{$\mathrm{N} / \mathrm{A}$} & Sunflower oil (ml)7 & 7 & 291 & \multirow{2}{*}{\multicolumn{2}{|c|}{$\begin{array}{l}\text { * The recommended diet } \\
\text { does not contain } \\
\text { discretionary choices. }\end{array}$}} \\
\hline & & & Olive oil (ml) & 7 & 291 & & \\
\hline
\end{tabular}

\section{Additional File 2}

Calculations of indicative low disposable household incomes for the reference household per fortnight

\begin{tabular}{|c|c|c|}
\hline Income source & $\begin{array}{l}\text { Indicative low disposable } \\
\text { household income (in 2019) }\end{array}$ & $\begin{array}{l}\text { Indicative low disposable household income, including government } \\
\text { supplements due to the SARS-CoV-2 pandemic (in 2020) }\end{array}$ \\
\hline Paid employment - adult male & $\$ 1,481.24$ & $\$ 1,481.24$ \\
\hline Paid employment - adult female & $\$ 233.88$ & $\$ 233.88$ \\
\hline JobSeeker & $\mathrm{N} / \mathrm{A}$ & $\$ 324.05$ \\
\hline Family Tax Benefit A fortnightly payment & $\$ 428.40$ & $\$ 428.40$ \\
\hline Family Tax Benefit A annual supplement & $\begin{array}{l}\$ 57.84 \text { ( } \$ 751.90 \text { per child per } \\
\text { year) }\end{array}$ & $\$ 58.96$ (\$766.50 per child per year) \\
\hline Family Tax Benefit B fortnightly payment & $\$ 107.66$ & $\$ 74.06$ \\
\hline Family Tax Benefit B annual supplement & $\begin{array}{l}\$ 14.04 \text { ( } \$ 365 \text { per family per } \\
\text { year) }\end{array}$ & $\$ 14.32$ (\$372.3 per family per year) \\
\hline Total Clean Energy Supplement & $\mathrm{N} / \mathrm{A}$ & $\$ 7.90$ \\
\hline Rent Assistance & $\$ 161.14$ & $\$ 164.08$ \\
\hline Economic Support Payment & $\mathrm{N} / \mathrm{A}$ & $\$ 125$ (One off \$750 payment in April 2020) \\
\hline Coronavirus Supplement & $\mathrm{N} / \mathrm{A}$ & $\$ 550.00$ (from April 27 - September 24, 2020) \\
\hline $\begin{array}{l}\text { Income tax payable (including tax offsets } \\
\text { \& Medicare levy if applicable) }\end{array}$ & $-\$ 125.87$ & $-\$ 125.87$ \\
\hline Total fortnightly income & $\$ 2,358.33$ & $\$ 3,336.02$ \\
\hline
\end{tabular}

\section{Additional File 3.}

Healthy Diets ASAP (Australian Standardised Affordability and Price) Survey Form 


\begin{tabular}{|c|c|c|c|c|c|c|}
\hline Food & Specific brand & $\begin{array}{l}\text { Your } \\
\text { brand }\end{array}$ & $\begin{array}{l}\text { Specific } \\
\text { size }\end{array}$ & $\begin{array}{l}\text { Your } \\
\text { size }\end{array}$ & $\begin{array}{l}\text { Your } \\
\text { cost }\end{array}$ & Comments \\
\hline \multicolumn{7}{|l|}{ Drinks } \\
\hline Bottled water, still & Mt Franklin & & $600 \mathrm{~mL}$ & & & \\
\hline Soft drink, Cola & Coca Cola & & $1.25 \mathrm{~L}$ & & & \\
\hline Diet soft drink, Cola & Coca Cola & & $1.25 \mathrm{~L}$ & & & \\
\hline Orange Juice, Australian Grown (Fresh, chilled) & Berri & & $2 \mathrm{~L}$ & & & \\
\hline \multicolumn{7}{|l|}{ Frozen Foods } \\
\hline $\begin{array}{l}\text { Frozen mixed vegetables (cheapest specified } \\
\text { brand) }\end{array}$ & Heinz, Birdseye or McCain & & $500 \mathrm{~g}$ & & & \\
\hline Frozen peas (cheapest specified brand) & Edgell, Birdseye or McCain & & $500 \mathrm{~g}$ & & & \\
\hline Beef lasagne, frozen & McCain & & $400 \mathrm{~g}$ & & & \\
\hline White crumbed fish fillet, frozen & Birds Eye & & $425 \mathrm{~g}$ & & & \\
\hline Vanilla Ice cream, regular fat & Nestle Peters Original & & $2 \mathrm{~L}$ & & & \\
\hline \multicolumn{7}{|l|}{ Other Items } \\
\hline Whole Barbeque Chicken, cooked - Large/ Family & Supermarket & & $\begin{array}{l}\text { Per unit } \\
\sim 1.5 \mathrm{~kg}\end{array}$ & & & \\
\hline $\begin{array}{l}\text { Pre-made Chicken \& Salad Sandwich } \\
\text { (wholemeal) ( } 1 \text { sandwich }=\sim 220 \mathrm{~g})\end{array}$ & $\begin{array}{l}\text { Supermarket or, if unavailable, at closest } \\
\text { garage/service station }\end{array}$ & & $\begin{array}{l}\text { 2sl bread + } \\
\text { filling } \\
\text { (triangle } \\
\text { pre-pack) }\end{array}$ & & & \\
\hline
\end{tabular}

Items from other stores:

\begin{tabular}{|c|c|c|c|c|c|c|}
\hline Food & Store & Your store & Specific size & Your size & Your cost & Comments \\
\hline \multirow[t]{2}{*}{ Cooked hot potato chips } & \multirow[t]{2}{*}{ Independent Fish \& Chip shop } & & $\sim 110 \mathrm{~g}$ & & & \\
\hline & & & 1 serve & & & \\
\hline Beef hamburger (Big Mac) & McDonald's & & 1 burger & & & \\
\hline \multirow[t]{2}{*}{ Beef Pie, single serve, full pastry } & \multirow[t]{2}{*}{ Independent Bakery } & & $\sim 250 \mathrm{~g}$ & & & \\
\hline & & & 1 pie & & & \\
\hline Supreme Pizza, thin base $(1$ pizza $=0.55 \mathrm{~kg})$ & Pizza Hut & & 1 large pizza & & & \\
\hline
\end{tabular}

Liquor Store Name:

\begin{tabular}{|c|c|c|c|c|c|c|}
\hline Food & Specific brand & Your brand & Specific size & Your size & Your cost & Comments \\
\hline Beer & VB & & $6 \times 375 \mathrm{~mL}$ & & & \\
\hline Sparkling white wine & Yellow & & $750 \mathrm{~mL}$ & & & \\
\hline Whisky & Johnny Walker Red Label & & $700 \mathrm{~mL}$ & & & \\
\hline Red wine & Penfolds Koonungara Hill Shiraz & & $750 \mathrm{~mL}$ & & & \\
\hline
\end{tabular}

\section{Additional File 4.}

Cost and affordability of the current and recommended diets for the reference household per fortnight, in randomly selected locations in Queensland (SEIFA Quintile 1 - most disadvantaged; Quintile 5 - least disadvantaged.) 


\begin{tabular}{|c|c|c|c|c|c|c|c|c|c|}
\hline $\begin{array}{l}\text { SA2 area } \\
\text { (deidentified) }\end{array}$ & \multicolumn{4}{|l|}{ Comm1 } & \multicolumn{4}{|l|}{ Comm2 } & Comm3 \\
\hline $\begin{array}{l}\text { SEIFA SA2 } \\
\text { quintile }\end{array}$ & \multicolumn{4}{|l|}{1} & \multicolumn{4}{|l|}{1} & 1 \\
\hline $\begin{array}{l}\text { ARIA+ } \\
\text { category }\end{array}$ & \multicolumn{4}{|c|}{ Major cities } & \multicolumn{4}{|c|}{ Major cities } & Major citi \\
\hline \multicolumn{10}{|c|}{ Total diet and food group costs } \\
\hline \multirow{2}{*}{$\begin{array}{l}\text { Food/food } \\
\text { groups }\end{array}$} & \multicolumn{2}{|c|}{ Current diet } & \multicolumn{2}{|c|}{ Recommended diet } & \multicolumn{2}{|c|}{ Current diet } & \multicolumn{2}{|c|}{ Recommended diet } & \multirow{2}{*}{$\begin{array}{l}\text { Current d } \\
\text { Mean } \\
\text { cost } \pm \\
\text { SD } \\
\text { (AS) }\end{array}$} \\
\hline & $\begin{array}{l}\text { Mean } \\
\text { cost } \pm \\
\text { SD } \\
\text { (A\$) }\end{array}$ & $\begin{array}{l}\text { Proportion } \\
\text { of total } \\
\text { cost (\%) }\end{array}$ & $\begin{array}{l}\text { Mean cost } \pm \text { SD } \\
\text { (AS) }\end{array}$ & $\begin{array}{l}\text { Proportion of } \\
\text { total cost (\%) }\end{array}$ & $\begin{array}{l}\text { Mean } \\
\text { cost } \pm \\
\text { SD } \\
\text { (AS) }\end{array}$ & $\begin{array}{l}\text { Proportion } \\
\text { of total } \\
\text { cost (\%) }\end{array}$ & $\begin{array}{l}\text { Mean cost } \pm \text { SD } \\
\text { (AS) }\end{array}$ & $\begin{array}{l}\text { Proportion of } \\
\text { total cost (\%) }\end{array}$ & \\
\hline $\begin{array}{l}\text { Water, } \\
\text { bottled }\end{array}$ & $\begin{array}{r}22.95 \\
\pm 4.01\end{array}$ & $3 \%$ & $22.95 \pm 4.01$ & $4 \%$ & $\begin{array}{l}22.80 \\
\pm 3.82\end{array}$ & $3 \%$ & $22.80 \pm 3.82$ & $4 \%$ & $\begin{array}{l}17.33 \\
\pm 4.44\end{array}$ \\
\hline Fruit & $\begin{array}{r}49.75 \\
\pm 4.82\end{array}$ & $6 \%$ & $60.67 \pm 12.47$ & $10 \%$ & $\begin{array}{l}54.53 \\
\pm 7.11\end{array}$ & $7 \%$ & $68.81 \pm 2.35$ & $11 \%$ & $\begin{array}{l}56.23 \\
\pm 9.01\end{array}$ \\
\hline $\begin{array}{l}\text { Vegetables } \\
\text { (\& legumes) }\end{array}$ & $\begin{array}{r}43.08 \\
\pm 1.21\end{array}$ & $6 \%$ & $107.99 \pm 3.63$ & $18 \%$ & $\begin{array}{l}42.34 \\
\pm 0.56\end{array}$ & $6 \%$ & $109.35 \pm 1.96$ & $18 \%$ & $\begin{array}{l}44.43 \\
\pm 2.10\end{array}$ \\
\hline $\begin{array}{l}\text { Grain } \\
\text { (cereal) } \\
\text { foods }\end{array}$ & $\begin{array}{r}45.39 \\
\pm 5.78\end{array}$ & $6 \%$ & $112.32 \pm 9.33$ & $18 \%$ & $\begin{array}{l}41.66 \\
\pm 1.58\end{array}$ & $5 \%$ & $109.60 \pm 3.06$ & $18 \%$ & $\begin{array}{l}42.83 \\
\pm 1.08\end{array}$ \\
\hline $\begin{array}{l}\text { Lean meats, } \\
\text { poultry, fish, } \\
\text { eggs, nuts, } \\
\text { seeds \& } \\
\text { alternatives }\end{array}$ & $\begin{array}{c}99.19 \\
\pm 14.91\end{array}$ & $13 \%$ & $188.22 \pm 22.99$ & $31 \%$ & $\begin{array}{l}98.23 \\
\pm 4.37\end{array}$ & $13 \%$ & $187.94 \pm 10.88$ & $30 \%$ & $\begin{array}{l}91.74 \\
\pm \\
12.87\end{array}$ \\
\hline $\begin{array}{l}\text { Milk, } \\
\text { yoghurt, } \\
\text { cheese \& } \\
\text { alternatives }\end{array}$ & $\begin{array}{r}48.40 \\
\pm 3.36\end{array}$ & $6 \%$ & $111.00 \pm 6.20$ & $18 \%$ & $\begin{array}{l}49.40 \\
\pm 4.57\end{array}$ & $6 \%$ & $110.85 \pm 5.78$ & $18 \%$ & $\begin{array}{l}47.81 \\
\pm 2.34\end{array}$ \\
\hline $\begin{array}{l}\text { Unsaturated } \\
\text { oils and } \\
\text { spreads }\end{array}$ & $\begin{array}{l}1.25 \pm \\
0.03\end{array}$ & $<1 \%$ & $8.07 \pm 1.39$ & $1 \%$ & $\begin{array}{l}1.31 \pm \\
0.09\end{array}$ & $<1 \%$ & $8.44 \pm 0.73$ & $1 \%$ & $\begin{array}{l}1.25 \pm \\
0.01\end{array}$ \\
\hline $\begin{array}{l}\text { Artificially } \\
\text { sweetened } \\
\text { beverages }\end{array}$ & $\begin{array}{l}4.86 \pm \\
0.11\end{array}$ & $1 \%$ & - & - & $\begin{array}{l}5.80 \pm \\
0.57\end{array}$ & $1 \%$ & - & - & $\begin{array}{l}6.23 \pm \\
1.08\end{array}$ \\
\hline $\begin{array}{l}\text { Sugar } \\
\text { sweetened } \\
\text { beverages }\end{array}$ & $\begin{array}{r}29.31 \\
\pm 0.68\end{array}$ & $4 \%$ & - & - & $\begin{array}{l}32.64 \\
\pm 3.35\end{array}$ & $4 \%$ & - & - & $\begin{array}{l}32.96 \\
\pm 3.81\end{array}$ \\
\hline $\begin{array}{l}\text { Takeaway } \\
\text { foods }\end{array}$ & $\begin{array}{l}143.31 \\
\pm 0.00\end{array}$ & $19 \%$ & - & - & $\begin{array}{l}140.76 \\
\pm 0.00\end{array}$ & $18 \%$ & - & - & $\begin{array}{l}145.24 \\
\pm 0.00\end{array}$ \\
\hline $\begin{array}{l}\text { Alcoholic } \\
\text { beverages }\end{array}$ & $\begin{array}{r}99.79 \\
\pm 0.00\end{array}$ & $13 \%$ & - & - & $\begin{array}{l}81.71 \\
\pm 0.00\end{array}$ & $11 \%$ & - & - & $\begin{array}{l}99.79 \\
\pm 0.00\end{array}$ \\
\hline $\begin{array}{l}\text { All other } \\
\text { discretionary } \\
\text { choices }\end{array}$ & $\begin{array}{r}181.56 \\
\pm 10.17\end{array}$ & $24 \%$ & - & - & $\begin{array}{l}191.01 \\
\pm \\
23.07\end{array}$ & $25 \%$ & - & - & $\begin{array}{l}184.90 \\
\pm \\
20.52\end{array}$ \\
\hline TOTAL diet & $\begin{array}{r}768.82 \\
\pm 13.12\end{array}$ & $100 \%$ & $611.21 \pm 21.07$ & $100 \%$ & $\begin{array}{l}762.20 \\
\pm \\
36.38\end{array}$ & $100 \%$ & $617.79 \pm 6.90$ & $100 \%$ & $\begin{array}{l}770.73 \\
\pm \\
22.01\end{array}$ \\
\hline $\begin{array}{l}\text { Healthy } \\
\text { foods and } \\
\text { drinks }\end{array}$ & $\begin{array}{l}314.85 \\
\pm 8.23\end{array}$ & $41 \%$ & $611.21 \pm 21.07$ & $100 \%$ & $\begin{array}{l}316.07 \\
\pm \\
10.71\end{array}$ & $41 \%$ & $617.79 \pm 6.90$ & $100 \%$ & $\begin{array}{l}307.85 \\
\pm 4.54\end{array}$ \\
\hline $\begin{array}{l}\text { Discretionary } \\
\text { foods and } \\
\text { drinks }\end{array}$ & $\begin{array}{l}453.96 \\
\pm 9.86\end{array}$ & $59 \%$ & - & - & $\begin{array}{l}446.13 \\
\pm \\
26.42\end{array}$ & $59 \%$ & - & - & $\begin{array}{l}462.88 \\
\pm \\
24.25\end{array}$ \\
\hline \multicolumn{10}{|c|}{ Income and diet affordability } \\
\hline $\begin{array}{l}\text { Income } \\
\text { categories }\end{array}$ & \multicolumn{2}{|c|}{ Income (A\$) } & $\begin{array}{l}\text { Current diet } \\
\text { affordability } \\
\text { (\% of income) }\end{array}$ & $\begin{array}{l}\text { Recommended } \\
\text { diet } \\
\text { affordability } \\
\text { (\% of income) }\end{array}$ & \multicolumn{2}{|c|}{ Income (A\$) } & $\begin{array}{l}\text { Current diet } \\
\text { affordability } \\
\text { (\% of income) }\end{array}$ & $\begin{array}{l}\text { Recommended } \\
\text { diet } \\
\text { affordability } \\
\text { (\% of income) }\end{array}$ & Income ( $/$ \\
\hline $\begin{array}{l}\text { Median } \\
\text { gross } \\
\text { household } \\
\text { income* }\end{array}$ & \multicolumn{2}{|l|}{1971.34} & $39 \%$ & $31 \%$ & \multicolumn{2}{|l|}{2272.66} & $34 \%$ & $27 \%$ & 2340.57 \\
\hline
\end{tabular}




\begin{tabular}{|c|c|c|c|c|c|c|c|}
\hline $\begin{array}{l}\text { Indicative } \\
\text { low } \\
\text { disposable } \\
\text { household } \\
\text { income }\end{array}$ & 2358.33 & $33 \%$ & $26 \%$ & 2358.33 & $32 \%$ & $26 \%$ & 2358.33 \\
\hline $\begin{array}{l}\text { Indicative } \\
\text { low } \\
\text { disposable } \\
\text { household } \\
\text { income } \\
\text { including } \\
\text { government } \\
\text { supplements } \\
\text { due to the } \\
\text { SARS-CoV-2 } \\
\text { pandemic }\end{array}$ & 3336.02 & $23 \%$ & $18 \%$ & 3336.02 & $23 \%$ & $19 \%$ & 3336.02 \\
\hline
\end{tabular}




\begin{tabular}{|c|c|c|c|c|c|c|c|c|c|}
\hline $\begin{array}{l}\text { SA2 area } \\
\text { (deidentified) }\end{array}$ & \multicolumn{4}{|l|}{ Comm4 } & \multicolumn{4}{|l|}{ Comm5 } & Comm6 \\
\hline $\begin{array}{l}\text { SEIFA SA2 } \\
\text { quintile }\end{array}$ & \multicolumn{4}{|l|}{1} & \multicolumn{4}{|l|}{1} & 1 \\
\hline $\begin{array}{l}\text { ARIA+ } \\
\text { category }\end{array}$ & \multicolumn{4}{|c|}{ Outer regional } & \multicolumn{4}{|c|}{ Outer regional } & Very remc \\
\hline \multicolumn{10}{|c|}{ Total diet and food group costs } \\
\hline \multirow{2}{*}{$\begin{array}{l}\text { Food/food } \\
\text { groups }\end{array}$} & \multicolumn{2}{|c|}{ Current diet } & \multicolumn{2}{|c|}{ Recommended diet } & \multicolumn{2}{|c|}{ Current diet } & \multicolumn{2}{|c|}{ Recommended diet } & \multirow{2}{*}{$\begin{array}{l}\text { Current di } \\
\text { Mean } \\
\text { cost } \pm \\
\text { SD (A\$\$) }\end{array}$} \\
\hline & $\begin{array}{l}\text { Mean } \\
\text { cost } \pm \\
\text { SD } \\
\text { (AS) }\end{array}$ & $\begin{array}{l}\text { Proportion } \\
\text { of total } \\
\text { cost (\%) }\end{array}$ & $\begin{array}{l}\text { Mean cost } \pm \text { SD } \\
(A S)\end{array}$ & $\begin{array}{l}\text { Proportion of } \\
\text { total cost (\%) }\end{array}$ & $\begin{array}{l}\text { Mean } \\
\text { cost } \pm \\
\text { SD } \\
\text { (AS) }\end{array}$ & $\begin{array}{l}\text { Proportion } \\
\text { of total } \\
\text { cost (\%) }\end{array}$ & $\begin{array}{l}\text { Mean cost } \pm \text { SD } \\
(A S)\end{array}$ & $\begin{array}{l}\text { Proportion of } \\
\text { total cost (\%) }\end{array}$ & \\
\hline $\begin{array}{l}\text { Water, } \\
\text { bottled }\end{array}$ & $\begin{array}{l}8.89 \pm \\
0.64\end{array}$ & $1 \%$ & $8.89 \pm 0.64$ & $1 \%$ & $\begin{array}{l}14.68 \\
\pm 7.07\end{array}$ & $2 \%$ & $14.68 \pm 7.07$ & $2 \%$ & $\begin{array}{l}8.83 \pm \\
0.00\end{array}$ \\
\hline Fruit & $\begin{array}{l}56.98 \\
\pm 0.03\end{array}$ & $8 \%$ & $79.07 \pm 4.94$ & $12 \%$ & $\begin{array}{l}56.52 \\
\pm 1.61\end{array}$ & $8 \%$ & $89.65 \pm 2.01$ & $15 \%$ & $\begin{array}{l}64.87 \pm \\
0.00\end{array}$ \\
\hline $\begin{array}{l}\text { Vegetables } \\
\text { (\& legumes) }\end{array}$ & $\begin{array}{l}41.45 \\
\pm 0.87\end{array}$ & $6 \%$ & $113.99 \pm 0.37$ & $18 \%$ & $\begin{array}{l}40.01 \\
\pm 0.22\end{array}$ & $5 \%$ & $105.04 \pm 4.34$ & $17 \%$ & $\begin{array}{l}48.64 \pm \\
0.00\end{array}$ \\
\hline $\begin{array}{l}\text { Grain } \\
\text { (cereal) } \\
\text { foods }\end{array}$ & $\begin{array}{l}41.75 \\
\pm 3.16\end{array}$ & $6 \%$ & $106.06 \pm 3.42$ & $17 \%$ & $\begin{array}{l}41.15 \\
\pm 0.75\end{array}$ & $5 \%$ & $98.90 \pm 5.39$ & $16 \%$ & $\begin{array}{l}62.70 \pm \\
0.00\end{array}$ \\
\hline $\begin{array}{l}\text { Lean meats, } \\
\text { poultry, fish, } \\
\text { eggs, nuts, } \\
\text { seeds \& } \\
\text { alternatives }\end{array}$ & $\begin{array}{l}105.39 \\
\pm 0.44\end{array}$ & $15 \%$ & $209.27 \pm 5.95$ & $33 \%$ & $\begin{array}{l}97.12 \\
\pm 3.22\end{array}$ & $13 \%$ & $186.06 \pm 6.14$ & $30 \%$ & $\begin{array}{l}134.30 \\
\pm 0.00\end{array}$ \\
\hline $\begin{array}{l}\text { Milk, } \\
\text { yoghurt, } \\
\text { cheese \& } \\
\text { alternatives }\end{array}$ & $\begin{array}{l}50.73 \\
\pm 0.78\end{array}$ & $7 \%$ & $111.88 \pm 0.98$ & $18 \%$ & $\begin{array}{l}49.15 \\
\pm 1.01\end{array}$ & $7 \%$ & $113.44 \pm 3.20$ & $18 \%$ & $\begin{array}{l}76.11 \pm \\
0.00\end{array}$ \\
\hline $\begin{array}{l}\text { Unsaturated } \\
\text { oils and } \\
\text { spreads }\end{array}$ & $\begin{array}{l}1.25 \pm \\
0.00\end{array}$ & $<1 \%$ & $8.24 \pm 0.05$ & $1 \%$ & $\begin{array}{l}1.05 \pm \\
0.25\end{array}$ & $<1 \%$ & $7.05 \pm 0.83$ & $1 \%$ & $\begin{array}{l}1.75 \pm \\
0.00\end{array}$ \\
\hline $\begin{array}{l}\text { Artificially } \\
\text { sweetened } \\
\text { beverages }\end{array}$ & $\begin{array}{l}6.02 \pm \\
0.00\end{array}$ & $1 \%$ & - & - & $\begin{array}{l}5.16 \pm \\
1.02\end{array}$ & $1 \%$ & - & - & $\begin{array}{l}9.93 \pm \\
0.00\end{array}$ \\
\hline $\begin{array}{l}\text { Sugar } \\
\text { sweetened } \\
\text { beverages }\end{array}$ & $\begin{array}{l}30.27 \\
\pm 0.00\end{array}$ & $4 \%$ & - & - & $\begin{array}{l}25.95 \\
\pm 5.13\end{array}$ & $3 \%$ & - & - & $\begin{array}{l}51.80 \pm \\
0.00\end{array}$ \\
\hline $\begin{array}{l}\text { Takeaway } \\
\text { foods }\end{array}$ & $\begin{array}{l}86.69 \\
\pm 0.00\end{array}$ & $12 \%$ & - & - & $\begin{array}{l}159.38 \\
\pm 0.00\end{array}$ & $21 \%$ & - & - & $\begin{array}{l}241.59 \\
\pm 0.00\end{array}$ \\
\hline $\begin{array}{l}\text { Alcoholic } \\
\text { beverages }\end{array}$ & $\begin{array}{l}102.97 \\
\pm 0.00\end{array}$ & $15 \%$ & - & - & $\begin{array}{l}97.99 \\
\pm 0.00\end{array}$ & $13 \%$ & - & - & $\begin{array}{l}79.46 \pm \\
0.00\end{array}$ \\
\hline $\begin{array}{l}\text { All other } \\
\text { discretionary } \\
\text { choices }\end{array}$ & $\begin{array}{l}174.26 \\
\pm 11.8\end{array}$ & $25 \%$ & - & - & $\begin{array}{l}163.57 \\
\pm 2.48\end{array}$ & $22 \%$ & - & - & $\begin{array}{l}316.52 \\
\pm 0.00\end{array}$ \\
\hline TOTAL diet & $\begin{array}{l}706.66 \\
\pm \\
14.43\end{array}$ & $100 \%$ & $637.39 \pm 13.65$ & $100 \%$ & $\begin{array}{l}751.73 \\
\pm \\
18.06\end{array}$ & $100 \%$ & $614.82 \pm 5.48$ & $100 \%$ & $\begin{array}{l}1096.47 \\
\pm 0.00\end{array}$ \\
\hline $\begin{array}{l}\text { Healthy } \\
\text { foods and } \\
\text { drinks }\end{array}$ & $\begin{array}{l}312.48 \\
\pm 2.63\end{array}$ & $44 \%$ & $637.39 \pm 13.65$ & $100 \%$ & $\begin{array}{l}304.84 \\
\pm \\
10.50\end{array}$ & $41 \%$ & $614.82 \pm 5.48$ & $100 \%$ & $\begin{array}{l}407.11 \\
\pm 0.00\end{array}$ \\
\hline $\begin{array}{l}\text { Discretionary } \\
\text { foods and } \\
\text { drinks }\end{array}$ & $\begin{array}{l}394.18 \\
\pm \\
11.80\end{array}$ & $56 \%$ & - & - & $\begin{array}{l}446.89 \\
\pm 7.60\end{array}$ & $59 \%$ & - & - & $\begin{array}{l}689.36 \\
\pm 0.00\end{array}$ \\
\hline \multicolumn{10}{|c|}{ Income and diet affordability } \\
\hline $\begin{array}{l}\text { Income } \\
\text { categories }\end{array}$ & \multicolumn{2}{|c|}{ Income (A\$) } & $\begin{array}{l}\text { Current diet } \\
\text { affordability } \\
\text { (\% of income) }\end{array}$ & $\begin{array}{l}\text { Recommended } \\
\text { diet } \\
\text { affordability } \\
\text { (\% of income) }\end{array}$ & \multicolumn{2}{|c|}{ Income (A\$) } & $\begin{array}{l}\text { Current diet } \\
\text { affordability } \\
\text { (\% of income) }\end{array}$ & $\begin{array}{l}\text { Recommended } \\
\text { diet } \\
\text { affordability } \\
\text { (\% of income) }\end{array}$ & Income (A \\
\hline $\begin{array}{l}\text { Median } \\
\text { gross } \\
\text { household } \\
\text { income* }\end{array}$ & \multicolumn{2}{|l|}{2090.17} & $38 \%$ & $31 \%$ & \multicolumn{2}{|c|}{2166.56} & $35 \%$ & $28 \%$ & 2105.02 \\
\hline
\end{tabular}




\begin{tabular}{|c|c|c|c|c|c|c|c|}
\hline $\begin{array}{l}\text { Indicative } \\
\text { low } \\
\text { disposable } \\
\text { household } \\
\text { income }\end{array}$ & 2358.33 & $34 \%$ & $28 \%$ & 2358.33 & $32 \%$ & $26 \%$ & 2358.33 \\
\hline $\begin{array}{l}\text { Indicative } \\
\text { low } \\
\text { disposable } \\
\text { household } \\
\text { income } \\
\text { including } \\
\text { government } \\
\text { supplements } \\
\text { due to the } \\
\text { SARS-CoV-2 } \\
\text { pandemic }\end{array}$ & 3336.02 & $24 \%$ & $20 \%$ & 3336.02 & $23 \%$ & $18 \%$ & 3336.02 \\
\hline
\end{tabular}

*Mean of the median gross household income of all SA2 locations within the relevant classifications included

\begin{tabular}{|c|c|c|c|c|c|c|c|c|c|}
\hline $\begin{array}{l}\text { SA2 area } \\
\text { (deidentified) }\end{array}$ & \multicolumn{4}{|l|}{ Comm7 } & \multicolumn{4}{|l|}{ Comm8 } & Comm9 \\
\hline $\begin{array}{l}\text { SEIFA SA2 } \\
\text { quintile }\end{array}$ & \multicolumn{4}{|l|}{3} & \multicolumn{4}{|l|}{3} & 3 \\
\hline $\begin{array}{l}\text { ARIA+ } \\
\text { category }\end{array}$ & \multicolumn{4}{|c|}{ Major cities } & \multicolumn{4}{|c|}{ Major cities } & Major citis \\
\hline \multicolumn{10}{|c|}{ Total diet and food group costs } \\
\hline \multirow{2}{*}{$\begin{array}{l}\text { Food/food } \\
\text { groups }\end{array}$} & \multicolumn{2}{|c|}{ Current diet } & \multicolumn{2}{|c|}{ Recommended diet } & \multicolumn{2}{|c|}{ Current diet } & \multicolumn{2}{|c|}{ Recommended diet } & \multirow{2}{*}{$\begin{array}{l}\text { Current di } \\
\text { Mean } \\
\text { cost } \pm \\
\text { SD (AS) }\end{array}$} \\
\hline & $\begin{array}{l}\text { Mean } \\
\text { cost } \pm \\
\text { SD } \\
\text { (AS) }\end{array}$ & $\begin{array}{l}\text { Proportion } \\
\text { of total } \\
\text { cost (\%) }\end{array}$ & $\begin{array}{l}\text { Mean cost } \pm \text { SD } \\
\text { (AS) }\end{array}$ & $\begin{array}{l}\text { Proportion of } \\
\text { total cost (\%) }\end{array}$ & $\begin{array}{l}\text { Mean } \\
\text { cost } \pm \\
\text { SD } \\
\text { (AS) }\end{array}$ & $\begin{array}{l}\text { Proportion } \\
\text { of total } \\
\text { cost (\%) }\end{array}$ & $\begin{array}{l}\text { Mean cost } \pm \text { SD } \\
\text { (AS) }\end{array}$ & $\begin{array}{l}\text { Proportion of } \\
\text { total cost (\%) }\end{array}$ & \\
\hline $\begin{array}{l}\text { Water, } \\
\text { bottled }\end{array}$ & $\begin{array}{l}20.83 \\
\pm 1.62\end{array}$ & $3 \%$ & $20.83 \pm 1.62$ & $3 \%$ & $\begin{array}{l}20.15 \\
\pm 1.85\end{array}$ & $3 \%$ & $20.15 \pm 1.85$ & $3 \%$ & $\begin{array}{l}21.19 \pm \\
1.92\end{array}$ \\
\hline Fruit & $\begin{array}{l}50.68 \\
\pm 2.36\end{array}$ & $7 \%$ & $76.88 \pm 3.68$ & $12 \%$ & $\begin{array}{l}58.09 \\
\pm 8.65\end{array}$ & $7 \%$ & $82.85 \pm 11.00$ & $13 \%$ & $\begin{array}{l}51.97 \pm \\
6.09\end{array}$ \\
\hline $\begin{array}{l}\text { Vegetables } \\
\text { (\& legumes) }\end{array}$ & $\begin{array}{l}40.63 \\
\pm 1.24\end{array}$ & $5 \%$ & $102.39 \pm 3.61$ & $17 \%$ & $\begin{array}{l}45.52 \\
\pm 2.32\end{array}$ & $6 \%$ & $115.21 \pm 6.08$ & $18 \%$ & $\begin{array}{l}41.48 \pm \\
1.93\end{array}$ \\
\hline $\begin{array}{l}\text { Grain } \\
\text { (cereal) } \\
\text { foods }\end{array}$ & $\begin{array}{l}42.44 \\
\pm 0.79\end{array}$ & $6 \%$ & $107.24 \pm 1.35$ & $17 \%$ & $\begin{array}{l}43.50 \\
\pm 0.65\end{array}$ & $5 \%$ & $109.68 \pm 1.98$ & $17 \%$ & $\begin{array}{l}43.77 \pm \\
2.66\end{array}$ \\
\hline $\begin{array}{l}\text { Lean meats, } \\
\text { poultry, fish, } \\
\text { eggs, nuts, } \\
\text { seeds \& } \\
\text { alternatives }\end{array}$ & $\begin{array}{l}99.19 \\
\pm 6.53\end{array}$ & $13 \%$ & $192.30 \pm 13.77$ & $31 \%$ & $\begin{array}{l}99.78 \\
\pm 0.75\end{array}$ & $13 \%$ & $193.55 \pm 2.89$ & $30 \%$ & $\begin{array}{l}91.58 \pm \\
5.45\end{array}$ \\
\hline $\begin{array}{l}\text { Milk, } \\
\text { yoghurt, } \\
\text { cheese \& } \\
\text { alternatives }\end{array}$ & $\begin{array}{l}48.28 \\
\pm 2.44\end{array}$ & $6 \%$ & $110.88 \pm 1.10$ & $18 \%$ & $\begin{array}{l}49.63 \\
\pm 4.10\end{array}$ & $6 \%$ & $113.72 \pm 6.11$ & $18 \%$ & $\begin{array}{l}41.29 \pm \\
3.20\end{array}$ \\
\hline $\begin{array}{l}\text { Unsaturated } \\
\text { oils and } \\
\text { spreads }\end{array}$ & $\begin{array}{l}1.23 \pm \\
0.03\end{array}$ & $<1 \%$ & $8.55 \pm 0.88$ & $1 \%$ & $\begin{array}{l}1.26 \pm \\
0.03\end{array}$ & $<1 \%$ & $8.81 \pm 1.27$ & $1 \%$ & $\begin{array}{l}1.26 \pm \\
0.02\end{array}$ \\
\hline $\begin{array}{l}\text { Artificially } \\
\text { sweetened } \\
\text { beverages }\end{array}$ & $\begin{array}{l}6.02 \pm \\
0.00\end{array}$ & $1 \%$ & - & - & $\begin{array}{l}5.59 \pm \\
0.42\end{array}$ & $1 \%$ & - & - & $\begin{array}{l}6.01 \pm \\
1.39\end{array}$ \\
\hline $\begin{array}{l}\text { Sugar } \\
\text { sweetened } \\
\text { beverages }\end{array}$ & $\begin{array}{l}29.79 \\
\pm 0.68\end{array}$ & $4 \%$ & - & - & $\begin{array}{l}29.79 \\
\pm 0.68\end{array}$ & $4 \%$ & - & - & $\begin{array}{l}33.54 \pm \\
4.62\end{array}$ \\
\hline $\begin{array}{l}\text { Takeaway } \\
\text { foods }\end{array}$ & $\begin{array}{l}154.39 \\
\pm 0.00\end{array}$ & $20 \%$ & - & - & $\begin{array}{l}146.51 \\
\pm 0.00\end{array}$ & $18 \%$ & - & - & $\begin{array}{l}164.25 \\
\pm 0.00\end{array}$ \\
\hline $\begin{array}{l}\text { Alcoholic } \\
\text { beverages }\end{array}$ & $\begin{array}{l}99.79 \\
\pm 0.00\end{array}$ & $13 \%$ & - & - & $\begin{array}{l}99.79 \\
\pm 0.00\end{array}$ & $13 \%$ & - & - & $\begin{array}{l}95.3 \pm \\
0.00\end{array}$ \\
\hline All other & 170.57 & $22 \%$ & - & - & 193.48 & $24 \%$ & - & - & 173.48 \\
\hline
\end{tabular}




\begin{tabular}{|c|c|c|c|c|c|c|c|c|c|}
\hline \multirow{2}{*}{$\begin{array}{l}\text { discretionary } \\
\text { choices } \\
\text { TOTAL diet }\end{array}$} & \multicolumn{4}{|l|}{ \pm 3.51} & \multicolumn{4}{|l|}{$\stackrel{ \pm}{29.38}$} & \multirow{2}{*}{$\begin{array}{l} \pm 1.97 \\
765.11 \\
\pm 16.60\end{array}$} \\
\hline & $\begin{array}{l}763.83 \\
\pm 4.04\end{array}$ & $100 \%$ & $619.08 \pm 4.55$ & $100 \%$ & $\begin{array}{l}793.08 \\
\pm \\
42.98\end{array}$ & $100 \%$ & $643.97 \pm 26.69$ & $100 \%$ & \\
\hline $\begin{array}{l}\text { Healthy } \\
\text { foods and } \\
\text { drinks }\end{array}$ & $\begin{array}{l}309.30 \\
\pm 0.87\end{array}$ & $40 \%$ & $619.08 \pm 4.55$ & $100 \%$ & $\begin{array}{l}323.52 \\
\pm \\
14.28\end{array}$ & $41 \%$ & $643.97 \pm 26.69$ & $100 \%$ & $\begin{array}{l}298.55 \\
\pm 10.90\end{array}$ \\
\hline $\begin{array}{l}\text { Discretionary } \\
\text { foods and } \\
\text { drinks }\end{array}$ & $\begin{array}{l}454.53 \\
\pm 4.15\end{array}$ & $60 \%$ & - & - & $\begin{array}{l}469.57 \\
\pm 28.7\end{array}$ & $59 \%$ & - & - & $\begin{array}{l}466.56 \\
\pm 6.40\end{array}$ \\
\hline \multicolumn{10}{|c|}{ Income and diet affordability } \\
\hline $\begin{array}{l}\text { Income } \\
\text { categories }\end{array}$ & \multicolumn{2}{|c|}{ Income (A\$) } & $\begin{array}{l}\text { Current diet } \\
\text { affordability } \\
\text { (\% of income) }\end{array}$ & $\begin{array}{l}\text { Recommended } \\
\text { diet } \\
\text { affordability } \\
\text { (\% of income) }\end{array}$ & \multicolumn{2}{|c|}{ Income (A\$) } & $\begin{array}{l}\text { Current diet } \\
\text { affordability } \\
\text { (\% of income) }\end{array}$ & $\begin{array}{l}\text { Recommended } \\
\text { diet } \\
\text { affordability } \\
\text { (\% of income) }\end{array}$ & Income $(A$ \\
\hline $\begin{array}{l}\text { Median } \\
\text { gross } \\
\text { household } \\
\text { income }\end{array}$ & \multicolumn{2}{|l|}{2822.26} & $27 \%$ & $22 \%$ & \multicolumn{2}{|l|}{3388.83} & $23 \%$ & $19 \%$ & 2958.07 \\
\hline $\begin{array}{l}\text { Indicative } \\
\text { low } \\
\text { disposable } \\
\text { household } \\
\text { income }\end{array}$ & \multicolumn{2}{|l|}{2358.33} & $32 \%$ & $26 \%$ & \multicolumn{2}{|l|}{2358.33} & $34 \%$ & $27 \%$ & 2358.33 \\
\hline $\begin{array}{l}\text { Indicative } \\
\text { low } \\
\text { disposable } \\
\text { household } \\
\text { income } \\
\text { including } \\
\text { government } \\
\text { supplements } \\
\text { due to the } \\
\text { SARS-CoV-2 } \\
\text { pandemic }\end{array}$ & \multicolumn{2}{|l|}{3336.02} & $23 \%$ & $19 \%$ & \multicolumn{2}{|l|}{3336.02} & $24 \%$ & $19 \%$ & 3336.02 \\
\hline \multicolumn{10}{|c|}{ *Mean of the median gross household income of all SA2 locations within the relevant classifications included } \\
\hline $\begin{array}{l}\text { SA2 area } \\
\text { (deidentified) }\end{array}$ & \multicolumn{4}{|c|}{ Comm10 } & \multicolumn{4}{|c|}{ Comm11 } & Comm12 \\
\hline $\begin{array}{l}\text { SEIFA SA2 } \\
\text { quintile }\end{array}$ & \multicolumn{4}{|l|}{3} & \multicolumn{4}{|l|}{3} & 3 \\
\hline $\begin{array}{l}\text { ARIA+ } \\
\text { category }\end{array}$ & \multicolumn{4}{|c|}{ Major cities } & \multicolumn{4}{|c|}{ Outer regional } & Outer regi \\
\hline \multicolumn{10}{|c|}{ Total diet and food group costs } \\
\hline \multirow{2}{*}{$\begin{array}{l}\text { Food/food } \\
\text { groups }\end{array}$} & \multicolumn{2}{|c|}{ Current diet } & \multicolumn{2}{|c|}{ Recommended diet } & \multicolumn{2}{|c|}{ Current diet } & \multicolumn{2}{|c|}{ Recommended diet } & Current di \\
\hline & $\begin{array}{l}\text { Mean } \\
\text { cost } \pm \\
\text { SD } \\
\text { (A\$) }\end{array}$ & $\begin{array}{l}\text { Proportion } \\
\text { of total } \\
\text { cost (\%) }\end{array}$ & $\begin{array}{l}\text { Mean cost } \pm \text { SD } \\
\text { (AS) }\end{array}$ & $\begin{array}{l}\text { Proportion of } \\
\text { total cost (\%) }\end{array}$ & $\begin{array}{l}\text { Mean } \\
\text { cost } \pm \\
\text { SD } \\
\text { (A\$) }\end{array}$ & $\begin{array}{l}\text { Proportion } \\
\text { of total } \\
\text { cost (\%) }\end{array}$ & $\begin{array}{l}\text { Mean cost } \pm \text { SD } \\
\text { (AS) }\end{array}$ & $\begin{array}{l}\text { Proportion of } \\
\text { total cost (\%) }\end{array}$ & $\begin{array}{l}\text { Mean } \\
\text { cost } \pm \\
\text { SD (A\$) }\end{array}$ \\
\hline $\begin{array}{l}\text { Water, } \\
\text { bottled }\end{array}$ & $\begin{array}{l}18.98 \\
\pm 2.36\end{array}$ & $3 \%$ & $18.98 \pm 2.36$ & $3 \%$ & $\begin{array}{l}16.77 \\
\pm \\
11.60\end{array}$ & $2 \%$ & $16.77 \pm 11.60$ & $3 \%$ & $\begin{array}{l}17.46 \pm \\
7.12\end{array}$ \\
\hline Fruit & $\begin{array}{l}50.19 \\
\pm 5.07\end{array}$ & $7 \%$ & $67.52 \pm 8.55$ & $11 \%$ & $\begin{array}{l}58.01 \\
\pm 3.92\end{array}$ & $7 \%$ & $82.93 \pm 1.88$ & $13 \%$ & $\begin{array}{l}52.65 \pm \\
2.88\end{array}$ \\
\hline $\begin{array}{l}\text { Vegetables } \\
\text { (\& legumes) }\end{array}$ & $\begin{array}{l}44.66 \\
\pm 0.97\end{array}$ & $6 \%$ & $113.42 \pm 3.94$ & $19 \%$ & $\begin{array}{l}47.36 \\
\pm 0.94\end{array}$ & $5 \%$ & $118.94 \pm 1.76$ & $18 \%$ & $\begin{array}{l}41.01 \pm \\
1.43\end{array}$ \\
\hline $\begin{array}{l}\text { Grain } \\
\text { (cereal) } \\
\text { foods }\end{array}$ & $\begin{array}{l}44.26 \\
\pm 2.91\end{array}$ & $6 \%$ & $110.55 \pm 5.34$ & $18 \%$ & $\begin{array}{l}51.14 \\
\pm 5.85\end{array}$ & $6 \%$ & $118.91 \pm 11.61$ & $18 \%$ & $\begin{array}{l}44.09 \pm \\
0.60\end{array}$ \\
\hline $\begin{array}{l}\text { Lean meats, } \\
\text { poultry, fish, } \\
\text { eggs, nuts, } \\
\text { seeds \& } \\
\text { alternatives }\end{array}$ & $\begin{array}{l}96.76 \\
\pm 4.42\end{array}$ & $13 \%$ & $181.94 \pm 9.03$ & $30 \%$ & $\begin{array}{l}103.46 \\
\pm \\
11.84\end{array}$ & $12 \%$ & $194.07 \pm 21.63$ & $29 \%$ & $\begin{array}{l}91.26 \pm \\
5.69\end{array}$ \\
\hline $\begin{array}{l}\text { Milk, } \\
\text { yoghurt, } \\
\text { cheese \& } \\
\text { alternatives }\end{array}$ & $\begin{array}{l}46.03 \\
\pm 0.60\end{array}$ & $6 \%$ & $107.10 \pm 0.90$ & $18 \%$ & $\begin{array}{l}50.59 \\
\pm 4.21\end{array}$ & $6 \%$ & $119.26 \pm 7.95$ & $18 \%$ & $\begin{array}{l}45.18 \pm \\
1.3\end{array}$ \\
\hline
\end{tabular}




\begin{tabular}{|c|c|c|c|c|c|c|c|c|c|}
\hline $\begin{array}{l}\text { Unsaturated } \\
\text { oils and } \\
\text { spreads }\end{array}$ & $\begin{array}{l}1.19 \pm \\
0.06\end{array}$ & $<1 \%$ & $7.89 \pm 0.84$ & $1 \%$ & $\begin{array}{l}1.35 \pm \\
0.37\end{array}$ & $<1 \%$ & $9.01 \pm 3.01$ & $1 \%$ & $\begin{array}{l}1.07 \pm \\
0.21\end{array}$ \\
\hline $\begin{array}{l}\text { Artificially } \\
\text { sweetened } \\
\text { beverages }\end{array}$ & $\begin{array}{l}4.94 \pm \\
0.11\end{array}$ & $1 \%$ & - & - & $\begin{array}{l}6.64 \pm \\
0.44\end{array}$ & $1 \%$ & - & - & $\begin{array}{l}4.73 \pm \\
1.19\end{array}$ \\
\hline $\begin{array}{l}\text { Sugar } \\
\text { sweetened } \\
\text { beverages }\end{array}$ & $\begin{array}{l}29.79 \\
\pm 0.68\end{array}$ & $4 \%$ & - & - & $\begin{array}{l}33.35 \\
\pm 2.22\end{array}$ & $4 \%$ & - & - & $\begin{array}{l}25.47 \pm \\
6.79\end{array}$ \\
\hline $\begin{array}{l}\text { Takeaway } \\
\text { foods }\end{array}$ & $\begin{array}{l}145.36 \\
\pm 0.00\end{array}$ & $19 \%$ & - & - & $\begin{array}{l}208.42 \\
\pm 0.00\end{array}$ & $24 \%$ & - & - & $\begin{array}{l}153.09 \\
\pm 0.00\end{array}$ \\
\hline $\begin{array}{l}\text { Alcoholic } \\
\text { beverages }\end{array}$ & $\begin{array}{l}99.79 \\
\pm 0.00\end{array}$ & $13 \%$ & - & - & $\begin{array}{l}96.41 \\
\pm 0.00\end{array}$ & $11 \%$ & - & - & $\begin{array}{l}99.79 \pm \\
0.00\end{array}$ \\
\hline $\begin{array}{l}\text { All other } \\
\text { discretionary } \\
\text { choices }\end{array}$ & $\begin{array}{l}174.62 \\
\pm 6.17\end{array}$ & $23 \%$ & - & - & $\begin{array}{l}209.49 \\
\pm \\
37.96\end{array}$ & $24 \%$ & - & - & $\begin{array}{l}174.95 \\
\pm 11.63\end{array}$ \\
\hline TOTAL diet & $\begin{array}{l}756.56 \\
\pm \\
16.64\end{array}$ & $100 \%$ & $607.39 \pm 25.46$ & $100 \%$ & $\begin{array}{l}882.97 \\
\pm \\
69.43\end{array}$ & $100 \%$ & $659.90 \pm 46.69$ & $100 \%$ & $\begin{array}{l}750.74 \\
\pm 7.48\end{array}$ \\
\hline $\begin{array}{l}\text { Healthy } \\
\text { foods and } \\
\text { drinks }\end{array}$ & $\begin{array}{l}307.00 \\
\pm \\
11.12\end{array}$ & $41 \%$ & $607.39 \pm 25.46$ & $100 \%$ & $\begin{array}{l}335.31 \\
\pm \\
31.01\end{array}$ & $38 \%$ & $659.90 \pm 46.69$ & $100 \%$ & $\begin{array}{l}297.45 \\
\pm 9.06\end{array}$ \\
\hline $\begin{array}{l}\text { Discretionary } \\
\text { foods and } \\
\text { drinks }\end{array}$ & $\begin{array}{l}449.56 \\
\pm 5.52\end{array}$ & $59 \%$ & - & - & $\begin{array}{l}547.67 \\
\pm \\
40.11\end{array}$ & $62 \%$ & - & - & $\begin{array}{l}453.29 \\
\pm 4.85\end{array}$ \\
\hline \multicolumn{10}{|c|}{ Income and diet affordability } \\
\hline $\begin{array}{l}\text { Income } \\
\text { categories }\end{array}$ & \multicolumn{2}{|c|}{ Income (AS) } & $\begin{array}{l}\text { Current diet } \\
\text { affordability } \\
\text { (\% of income) }\end{array}$ & $\begin{array}{l}\text { Recommended } \\
\text { diet } \\
\text { affordability } \\
\text { (\% of income) }\end{array}$ & \multicolumn{2}{|c|}{ Income (A\$) } & $\begin{array}{l}\text { Current diet } \\
\text { affordability } \\
\text { (\% of income) }\end{array}$ & $\begin{array}{l}\text { Recommended } \\
\text { diet } \\
\text { affordability } \\
\text { (\% of income) }\end{array}$ & Income (A \\
\hline $\begin{array}{l}\text { Median } \\
\text { gross } \\
\text { household } \\
\text { income* }\end{array}$ & \multicolumn{2}{|l|}{3172.39} & $18 \%$ & $19 \%$ & \multicolumn{2}{|l|}{2236.59} & $39 \%$ & $30 \%$ & 3997.85 \\
\hline $\begin{array}{l}\text { Indicative } \\
\text { low } \\
\text { disposable } \\
\text { household } \\
\text { income }\end{array}$ & \multicolumn{2}{|l|}{2358.33} & $32 \%$ & $26 \%$ & \multicolumn{2}{|l|}{2358.33} & $37 \%$ & $28 \%$ & 2358.33 \\
\hline $\begin{array}{l}\text { Indicative } \\
\text { low } \\
\text { disposable } \\
\text { household } \\
\text { income } \\
\text { including } \\
\text { government } \\
\text { supplements } \\
\text { due to the } \\
\text { SARS-CoV-2 } \\
\text { pandemic }\end{array}$ & \multicolumn{2}{|l|}{3336.02} & $23 \%$ & $18 \%$ & \multicolumn{2}{|l|}{3336.02} & $26 \%$ & $20 \%$ & 3336.02 \\
\hline
\end{tabular}




\begin{tabular}{|c|c|c|c|c|c|c|c|c|c|}
\hline $\begin{array}{l}\text { SA2 area } \\
\text { (deidentified) }\end{array}$ & \multicolumn{4}{|l|}{ Comm13 } & \multicolumn{4}{|c|}{ Comm14 } & Comm1! \\
\hline $\begin{array}{l}\text { SEIFA SA2 } \\
\text { quintile }\end{array}$ & \multicolumn{4}{|l|}{3} & \multicolumn{4}{|l|}{5} & 5 \\
\hline $\begin{array}{l}\text { ARIA+ } \\
\text { category }\end{array}$ & \multicolumn{4}{|c|}{ Very remote } & \multicolumn{4}{|c|}{ Major cities } & Major cit \\
\hline \multicolumn{10}{|c|}{ Total diet and food group costs } \\
\hline \multirow{2}{*}{$\begin{array}{l}\text { Food/food } \\
\text { groups }\end{array}$} & \multicolumn{2}{|c|}{ Current diet } & \multicolumn{2}{|c|}{ Recommended diet } & \multicolumn{2}{|c|}{ Current diet } & \multicolumn{2}{|c|}{ Recommended diet } & \multirow{2}{*}{$\begin{array}{l}\text { Current c } \\
\text { Mean } \\
\text { cost } \pm \\
\text { SD } \\
\text { (AS) }\end{array}$} \\
\hline & $\begin{array}{l}\text { Mean } \\
\text { cost } \pm \\
\text { SD (A\$) }\end{array}$ & $\begin{array}{l}\text { Proportion } \\
\text { of total } \\
\text { cost (\%) }\end{array}$ & $\begin{array}{l}\text { Mean cost } \pm \text { SD } \\
\text { (AS) }\end{array}$ & $\begin{array}{l}\text { Proportion of } \\
\text { total cost (\%) }\end{array}$ & $\begin{array}{l}\text { Mean } \\
\text { cost } \pm \\
\text { SD } \\
\text { (AS) }\end{array}$ & $\begin{array}{l}\text { Proportion } \\
\text { of total } \\
\text { cost (\%) }\end{array}$ & $\begin{array}{l}\text { Mean cost } \pm \text { SD } \\
\text { (AS) }\end{array}$ & $\begin{array}{l}\text { Proportion of } \\
\text { total cost (\%) }\end{array}$ & \\
\hline $\begin{array}{l}\text { Water, } \\
\text { bottled }\end{array}$ & $\begin{array}{l}18.09 \pm \\
5.74\end{array}$ & $2 \%$ & $18.09 \pm 5.74$ & $2 \%$ & $\begin{array}{l}18.98 \\
\pm 1.30\end{array}$ & $2 \%$ & $18.98 \pm 1.30$ & $3 \%$ & $\begin{array}{l}20.30 \\
\pm 1.44\end{array}$ \\
\hline Fruit & $\begin{array}{l}73.54 \pm \\
1.82\end{array}$ & $7 \%$ & $113.15 \pm 8.86$ & $15 \%$ & $\begin{array}{l}62.32 \\
\pm \\
15.37\end{array}$ & $8 \%$ & $83.17 \pm 18.38$ & $12 \%$ & $\begin{array}{l}49.80 \\
\pm 3.33\end{array}$ \\
\hline $\begin{array}{l}\text { Vegetables } \\
\text { (\& legumes) }\end{array}$ & $\begin{array}{l}52.99 \pm \\
1.14\end{array}$ & $5 \%$ & $134.41 \pm 0.06$ & $17 \%$ & $\begin{array}{l}47.35 \\
\pm 4.86\end{array}$ & $6 \%$ & $121.05 \pm 11.92$ & $18 \%$ & $\begin{array}{l}42.94 \\
\pm 1.63\end{array}$ \\
\hline $\begin{array}{l}\text { Grain } \\
\text { (cereal) } \\
\text { foods }\end{array}$ & $\begin{array}{l}52.48 \pm \\
2.84\end{array}$ & $5 \%$ & $134.20 \pm 0.66$ & $17 \%$ & $\begin{array}{l}46.40 \\
\pm 6.27\end{array}$ & $6 \%$ & $108.36 \pm 11.67$ & $16 \%$ & $\begin{array}{l}44.33 \\
\pm 4.24\end{array}$ \\
\hline $\begin{array}{l}\text { Lean meats, } \\
\text { poultry, fish, } \\
\text { eggs, nuts, } \\
\text { seeds \& } \\
\text { alternatives }\end{array}$ & $\begin{array}{l}117.37 \\
\pm 0.83\end{array}$ & $11 \%$ & $230.96 \pm 2.21$ & $30 \%$ & $\begin{array}{l}102.12 \\
\pm 7.13\end{array}$ & $13 \%$ & $199.54 \pm 14.07$ & $30 \%$ & $\begin{array}{l}92.80 \\
\pm 7.26\end{array}$ \\
\hline $\begin{array}{l}\text { Milk, } \\
\text { yoghurt, } \\
\text { cheese \& } \\
\text { alternatives }\end{array}$ & $\begin{array}{l}58.16 \pm \\
2.46\end{array}$ & $6 \%$ & $136.43 \pm 9.53$ & $18 \%$ & $\begin{array}{l}52.52 \\
\pm 8.71\end{array}$ & $7 \%$ & $133.51 \pm 36.24$ & $20 \%$ & $\begin{array}{l}48.88 \\
\pm 3.94\end{array}$ \\
\hline $\begin{array}{l}\text { Unsaturated } \\
\text { oils and } \\
\text { spreads }\end{array}$ & $\begin{array}{l}1.55 \pm \\
0.08\end{array}$ & $<1 \%$ & $11.16 \pm 0.04$ & $1 \%$ & $\begin{array}{l}1.35 \pm \\
0.15\end{array}$ & $<1 \%$ & $9.22 \pm 1.84$ & $1 \%$ & $\begin{array}{l}1.25 \pm \\
0.02\end{array}$ \\
\hline $\begin{array}{l}\text { Artificially } \\
\text { sweetened } \\
\text { beverages }\end{array}$ & $\begin{array}{l}7.77 \pm \\
1.02\end{array}$ & $1 \%$ & - & - & $\begin{array}{l}5.89 \pm \\
1.23\end{array}$ & $1 \%$ & - & - & $\begin{array}{l}5.69 \pm \\
0.47\end{array}$ \\
\hline $\begin{array}{l}\text { Sugar } \\
\text { sweetened } \\
\text { beverages }\end{array}$ & $\begin{array}{l}39.06 \pm \\
5.14\end{array}$ & $4 \%$ & - & - & $\begin{array}{l}32.96 \\
\pm 3.81\end{array}$ & $4 \%$ & - & - & $\begin{array}{l}30.27 \\
\pm 0.00\end{array}$ \\
\hline $\begin{array}{l}\text { Takeaway } \\
\text { foods }\end{array}$ & $\begin{array}{l}209.55 \\
\pm 10.79\end{array}$ & $20 \%$ & - & - & $\begin{array}{l}147.47 \\
\pm 0.00\end{array}$ & $18 \%$ & - & - & $\begin{array}{l}158.58 \\
\pm 0.00\end{array}$ \\
\hline $\begin{array}{l}\text { Alcoholic } \\
\text { beverages }\end{array}$ & $\begin{array}{l}99.78 \pm \\
0.00\end{array}$ & $10 \%$ & - & - & $\begin{array}{l}88.11 \\
\pm 0.00\end{array}$ & $11 \%$ & - & - & $\begin{array}{l}99.79 \\
\pm 0.00\end{array}$ \\
\hline $\begin{array}{l}\text { All other } \\
\text { discretionary } \\
\text { choices }\end{array}$ & $\begin{array}{l}292.31 \\
\pm 56.66\end{array}$ & $29 \%$ & - & - & $\begin{array}{l}199.13 \\
\pm \\
38.46\end{array}$ & $25 \%$ & - & - & $\begin{array}{l}170.81 \\
\pm 2.86\end{array}$ \\
\hline TOTAL diet & $\begin{array}{l}1022.67 \\
\pm 48.89\end{array}$ & $100 \%$ & $778.40 \pm 15.51$ & $100 \%$ & $\begin{array}{l}804.61 \\
\pm \\
81.97\end{array}$ & $100 \%$ & $673.82 \pm 87.34$ & $100 \%$ & $\begin{array}{l}765.44 \\
\pm 9.33\end{array}$ \\
\hline $\begin{array}{l}\text { Healthy } \\
\text { foods and } \\
\text { drinks }\end{array}$ & $\begin{array}{l}381.97 \\
\pm 2.13\end{array}$ & $37 \%$ & $778.40 \pm 15.51$ & $100 \%$ & $\begin{array}{l}336.93 \\
\pm \\
39.82\end{array}$ & $42 \%$ & $673.82 \pm 87.34$ & $100 \%$ & $\begin{array}{l}305.99 \\
\pm 6.89\end{array}$ \\
\hline $\begin{array}{l}\text { Discretionary } \\
\text { foods and } \\
\text { drinks }\end{array}$ & $\begin{array}{l}640.70 \\
\pm 51.01\end{array}$ & $63 \%$ & - & - & $\begin{array}{l}467.67 \\
\pm \\
42.26\end{array}$ & $58 \%$ & - & - & $\begin{array}{l}459.45 \\
\pm 2.86\end{array}$ \\
\hline \multicolumn{10}{|c|}{ Income and diet affordability } \\
\hline $\begin{array}{l}\text { Income } \\
\text { categories }\end{array}$ & \multicolumn{2}{|c|}{ Income (A\$) } & $\begin{array}{l}\text { Current diet } \\
\text { affordability } \\
\text { (\% of income) }\end{array}$ & $\begin{array}{l}\text { Recommended } \\
\text { diet } \\
\text { affordability } \\
\text { (\% of income) }\end{array}$ & \multicolumn{2}{|c|}{ Income (A\$) } & $\begin{array}{l}\text { Current diet } \\
\text { affordability } \\
\text { (\% of income) }\end{array}$ & $\begin{array}{l}\text { Recommended } \\
\text { diet } \\
\text { affordability } \\
\text { (\% of income) }\end{array}$ & Income ( \\
\hline $\begin{array}{l}\text { Median } \\
\text { gross } \\
\text { household } \\
\text { income* }\end{array}$ & \multicolumn{2}{|l|}{2707.67} & $38 \%$ & $29 \%$ & \multicolumn{2}{|c|}{4110.31} & $20 \%$ & $16 \%$ & 4263.10 \\
\hline
\end{tabular}




\begin{tabular}{|c|c|c|c|c|c|c|c|}
\hline $\begin{array}{l}\text { Indicative } \\
\text { low } \\
\text { disposable } \\
\text { household } \\
\text { income }\end{array}$ & 2358.33 & $43 \%$ & $33 \%$ & 2358.33 & $34 \%$ & $29 \%$ & 2358.33 \\
\hline $\begin{array}{l}\text { Indicative } \\
\text { low } \\
\text { disposable } \\
\text { household } \\
\text { income } \\
\text { including } \\
\text { government } \\
\text { supplements } \\
\text { due to the } \\
\text { SARS-CoV-2 } \\
\text { pandemic }\end{array}$ & 3336.02 & $31 \%$ & $23 \%$ & 3336.02 & $24 \%$ & $20 \%$ & 3336.02 \\
\hline
\end{tabular}




\begin{tabular}{|c|c|c|c|c|c|c|c|c|}
\hline $\begin{array}{l}\text { SA2 area } \\
\text { (deidentified) }\end{array}$ & \multicolumn{4}{|c|}{ Comm16 } & \multicolumn{4}{|c|}{ Comm17 } \\
\hline SEIFA SA2 quintile & \multicolumn{4}{|l|}{5} & \multicolumn{4}{|l|}{5} \\
\hline ARIA+ category & \multicolumn{4}{|c|}{ Major cities } & \multicolumn{4}{|c|}{ Outer regional } \\
\hline \multicolumn{9}{|c|}{ Total diet and food group costs } \\
\hline \multirow[t]{2}{*}{ Food/food groups } & \multicolumn{2}{|c|}{ Current diet } & \multicolumn{2}{|c|}{ Recommended diet } & \multicolumn{2}{|c|}{ Current diet } & \multicolumn{2}{|c|}{ Recommended diet } \\
\hline & $\begin{array}{l}\text { Mean } \\
\text { cost } \pm \\
\text { SD } \\
\text { (AS) }\end{array}$ & $\begin{array}{l}\text { Proportion } \\
\text { of total } \\
\text { cost (\%) }\end{array}$ & $\begin{array}{l}\text { Mean cost } \pm \text { SD } \\
\text { (AS) }\end{array}$ & $\begin{array}{l}\text { Proportion of } \\
\text { total cost (\%) }\end{array}$ & $\begin{array}{l}\text { Mean } \\
\text { cost } \pm \\
\text { SD } \\
\text { (AS) }\end{array}$ & $\begin{array}{l}\text { Proportion } \\
\text { of total } \\
\text { cost (\%) }\end{array}$ & $\begin{array}{l}\text { Mean cost } \pm \text { SD } \\
\text { (AS) }\end{array}$ & $\begin{array}{l}\text { Proportion of } \\
\text { total cost }(\%)\end{array}$ \\
\hline Water, bottled & $\begin{array}{l}20.01 \\
\pm 1.50\end{array}$ & $3 \%$ & $20.01 \pm 1.50$ & $3 \%$ & $\begin{array}{l}20.08 \\
\pm 0.54\end{array}$ & $3 \%$ & $20.08 \pm 0.54$ & $3 \%$ \\
\hline Fruit & $\begin{array}{l}50.28 \\
\pm 5.24\end{array}$ & $7 \%$ & $63.72 \pm 4.53$ & $11 \%$ & $\begin{array}{l}56.52 \\
\pm 1.61\end{array}$ & $7 \%$ & $89.65 \pm 2.01$ & $14 \%$ \\
\hline $\begin{array}{l}\text { Vegetables ( } \\
\text { legumes) }\end{array}$ & $\begin{array}{l}43.51 \\
\pm 1.97\end{array}$ & $6 \%$ & $105.85 \pm 6.35$ & $17 \%$ & $\begin{array}{l}36.02 \\
\pm 0.67\end{array}$ & $5 \%$ & $105.34 \pm 4.37$ & $17 \%$ \\
\hline Grain (cereal) foods & $\begin{array}{l}48.81 \\
\pm 7.64\end{array}$ & $6 \%$ & $115.84 \pm 10.47$ & $19 \%$ & $\begin{array}{l}37.14 \\
\pm 0.75\end{array}$ & $5 \%$ & $100.06 \pm 5.1$ & $16 \%$ \\
\hline $\begin{array}{l}\text { Lean meats, poultry, } \\
\text { fish, eggs, nuts, seeds } \\
\text { \& alternatives }\end{array}$ & $\begin{array}{l}93.10 \\
\pm 3.73\end{array}$ & $12 \%$ & $173.89 \pm 5.42$ & $29 \%$ & $\begin{array}{l}92.52 \\
\pm 4.54\end{array}$ & $12 \%$ & $190.57 \pm 13.91$ & $30 \%$ \\
\hline $\begin{array}{l}\text { Milk, yoghurt, cheese } \\
\& \text { alternatives }\end{array}$ & $\begin{array}{l}47.10 \\
\pm 7.31\end{array}$ & $6 \%$ & $118.86 \pm 23.35$ & $20 \%$ & $\begin{array}{l}49.15 \\
\pm 1.01\end{array}$ & $6 \%$ & $113.46 \pm 3.22$ & $18 \%$ \\
\hline $\begin{array}{l}\text { Unsaturated oils and } \\
\text { spreads }\end{array}$ & $\begin{array}{l}1.40 \pm \\
0.23\end{array}$ & $<1 \%$ & $8.33 \pm 1.04$ & $1 \%$ & $\begin{array}{l}1.05 \pm \\
0.25\end{array}$ & $<1 \%$ & $7.05 \pm 0.84$ & $1 \%$ \\
\hline $\begin{array}{l}\text { Artificially sweetened } \\
\text { beverages }\end{array}$ & $\begin{array}{l}5.38 \pm \\
0.51\end{array}$ & $1 \%$ & - & - & $\begin{array}{l}5.16 \pm \\
1.02\end{array}$ & $1 \%$ & - & - \\
\hline $\begin{array}{l}\text { Sugar sweetened } \\
\text { beverages }\end{array}$ & $\begin{array}{l}30.40 \\
\pm 0.18\end{array}$ & $4 \%$ & - & - & $\begin{array}{l}25.95 \\
\pm 5.13\end{array}$ & $3 \%$ & - & - \\
\hline Takeaway foods & $\begin{array}{l}147.28 \\
\pm 0.00\end{array}$ & $19 \%$ & - & - & $\begin{array}{l}174.44 \\
\pm 0.00\end{array}$ & $23 \%$ & - & - \\
\hline Alcoholic beverages & $\begin{array}{l}99.79 \\
\pm 0.00\end{array}$ & $13 \%$ & - & - & $\begin{array}{l}101.53 \\
\pm 0.00\end{array}$ & $13 \%$ & - & - \\
\hline $\begin{array}{l}\text { All other discretionary } \\
\text { choices }\end{array}$ & $\begin{array}{l}184.62 \\
\pm \\
18.04\end{array}$ & $24 \%$ & - & - & $\begin{array}{l}171.74 \\
\pm 2.88\end{array}$ & $22 \%$ & - & - \\
\hline TOTAL diet & $\begin{array}{l}771.67 \\
\pm \\
41.32\end{array}$ & $100 \%$ & $606.48 \pm 40.68$ & $100 \%$ & $\begin{array}{l}771.30 \\
\pm 5.66\end{array}$ & $100 \%$ & $626.21 \pm 6.64$ & $100 \%$ \\
\hline $\begin{array}{l}\text { Healthy foods and } \\
\text { drinks }\end{array}$ & $\begin{array}{l}309.58 \\
\pm \\
23.48\end{array}$ & $40 \%$ & $606.48 \pm 40.68$ & $100 \%$ & $\begin{array}{l}297.64 \\
\pm 4.05\end{array}$ & $39 \%$ & $626.21 \pm 6.64$ & $100 \%$ \\
\hline $\begin{array}{l}\text { Discretionary foods } \\
\text { and drinks }\end{array}$ & $\begin{array}{l}462.09 \\
\pm \\
18.22\end{array}$ & $60 \%$ & - & - & $\begin{array}{l}473.66 \\
\pm 3.06\end{array}$ & $61 \%$ & - & - \\
\hline \multicolumn{9}{|c|}{ Income and diet affordability } \\
\hline Income categories & \multicolumn{2}{|c|}{ Income (A\$) } & $\begin{array}{l}\text { Current diet } \\
\text { affordability } \\
\text { (\% of income) }\end{array}$ & $\begin{array}{l}\text { Recommended } \\
\text { diet } \\
\text { affordability } \\
\text { (\% of income) }\end{array}$ & \multicolumn{2}{|c|}{ Income (A\$) } & $\begin{array}{l}\text { Current diet } \\
\text { affordability } \\
\text { (\% of income) }\end{array}$ & $\begin{array}{l}\text { Recommended } \\
\text { diet affordability } \\
\text { (\% of income) }\end{array}$ \\
\hline $\begin{array}{l}\text { Median gross } \\
\text { household income* }\end{array}$ & \multicolumn{2}{|c|}{4581.40} & $17 \%$ & $13 \%$ & \multicolumn{2}{|c|}{4011.64} & $20 \%$ & $16 \%$ \\
\hline $\begin{array}{l}\text { Indicative low } \\
\text { disposable } \\
\text { household income }\end{array}$ & \multicolumn{2}{|c|}{2358.33} & $33 \%$ & $26 \%$ & \multicolumn{2}{|l|}{2358.33} & $33 \%$ & $27 \%$ \\
\hline $\begin{array}{l}\text { Indicative low } \\
\text { disposable } \\
\text { household income } \\
\text { including government } \\
\text { supplements due to } \\
\text { the SARS-CoV-2 } \\
\text { pandemic }\end{array}$ & \multicolumn{2}{|c|}{3336.02} & $23 \%$ & $18 \%$ & \multicolumn{2}{|l|}{3336.02} & $24 \%$ & $19 \%$ \\
\hline
\end{tabular}




\section{Figures}

$\$ 1,400.00$

$\$ 1,200.00$

$\$ 1,000.00$

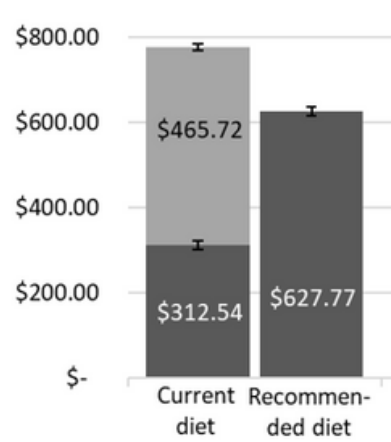

a

Least disadvantaged (SEIFA quintile 5)

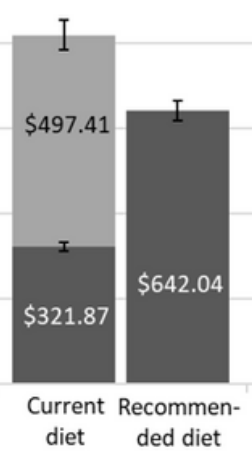

Median disadvantaged (SEIFA quintile 3)

\section{$\$ 1,400.00$}

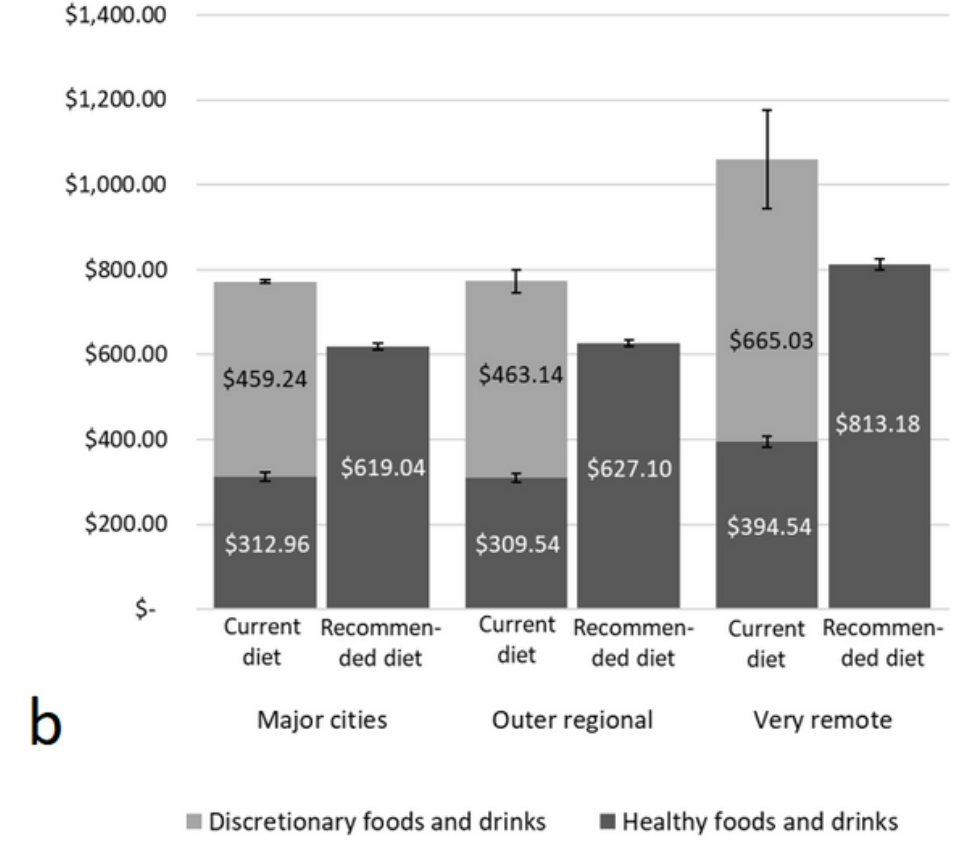

Discretionary foods and drinks

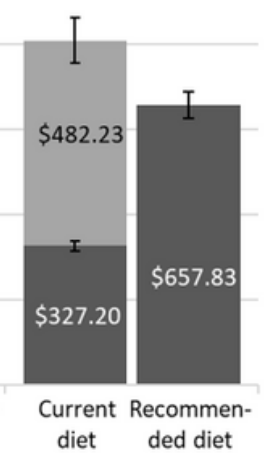

Most disadvantaged (SEIFA quintile 1)

Discretionary foods and drinks $\quad$ Healthy foods and drinks

Figure 1

Figure 1A Cost of current and recommended diets (A\$) for the reference household per fortnight, by area of socioeconomic disadvantage (selected SEIFA quintiles) in Queensland. (Error bars indicate the standard error.) Figure 1B The costs of current and recommended diets (A\$) for the reference household per fortnight, by remoteness (selected ARIA+ categories) in Queensland (Error bars indicate the standard error.)

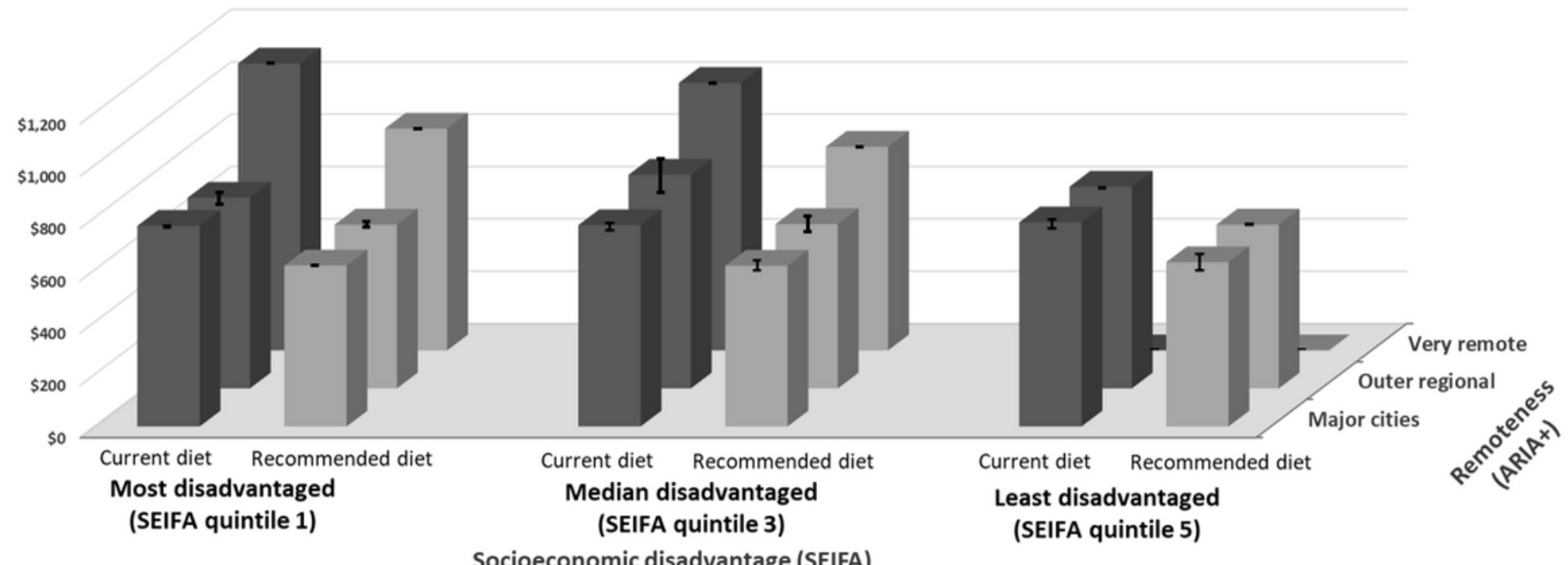

Figure 2

Figure 2 Cost of current and recommended diets for reference household per fortnight, by area of socioeconomic disadvantage (selected SEIFA quintiles) and remoteness (selected ARIA+ categories) in Queensland. (Error bars indicate the standard error.) 


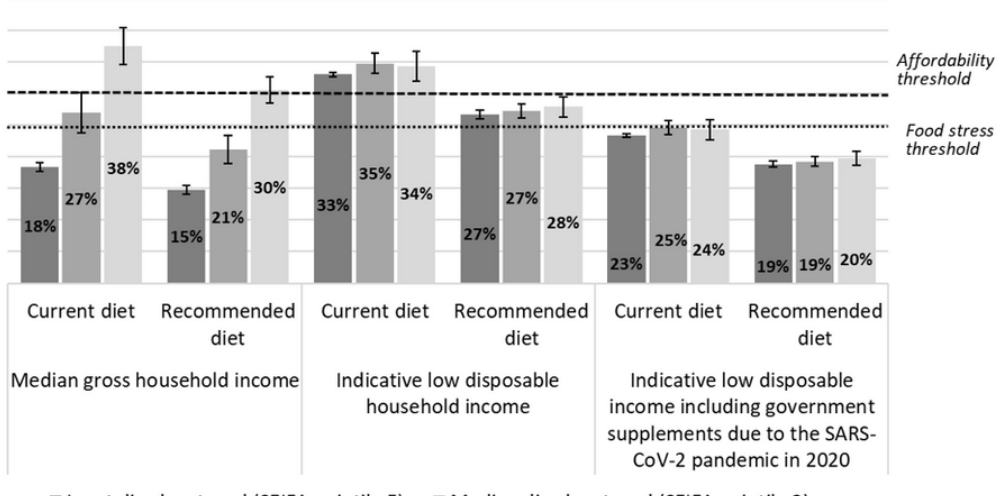

- Least disadvantaged (SEIFA quintile 5) Median disadvantaged (SEIFA quintile 3)

a Most disadvantaged (SEIFA quintile 1)

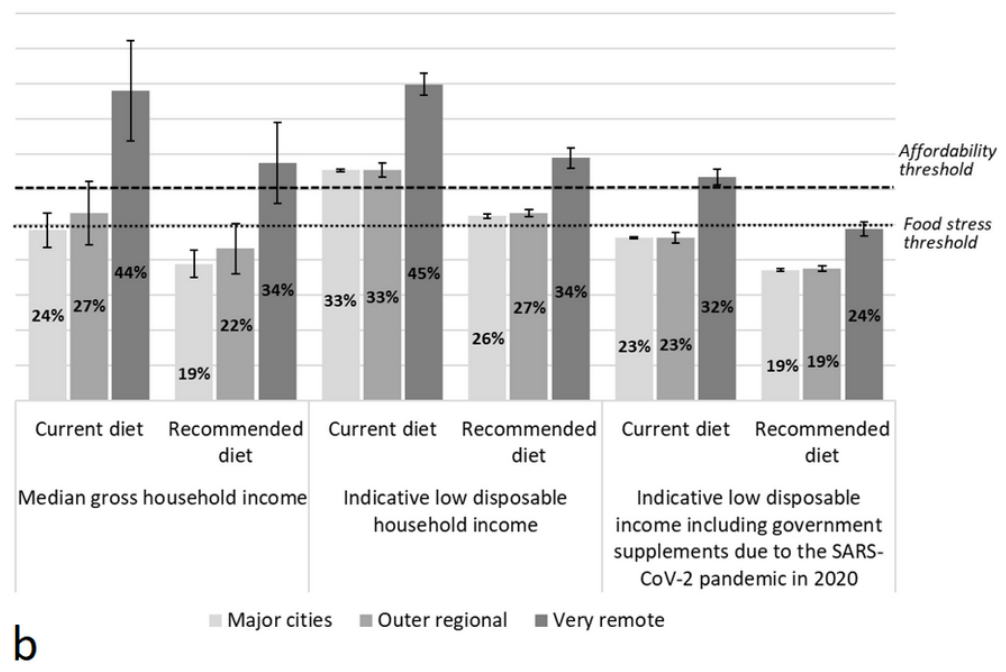

\section{Figure 3}

Figure 3A The affordability (\% of household income) of current and recommended diets, for the reference household, by income categorisation and by area of socioeconomic disadvantage (selected SEIFA quintiles). (Error bars indicate the standard error.) Figure 3B The affordability (\% of household income) of current and recommended diets, for the reference household, by income categorisation and by remoteness (selected ARIA+ categories). (Error bars indicate the standard error.) 